\title{
Analysis and interpretation of regional-scaled gravity measurements in the Central Equatorial Atlantic region of Africa
}

The Mining-Geology-Petroleum Engineering Bulletin UDC: 550.8

DOI: $10.17794 / \mathrm{rgn} .2020 .1 .7$

Original scientific paper

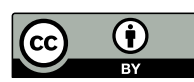

\author{
Oluwatimilehin B. Balogun ${ }^{\text {; }}$ Olajumoke C. Akintokewa ${ }^{1}$ \\ ${ }^{1}$ Department of Geology, Obafemi Awolowo University, Ile-Ife, Nigeria.
}

\begin{abstract}
Regional-scaled gravity data was interpreted for the Central Equatorial Atlantic African region, a region comprising of both oceanic and continental areas, with a view to understanding more about its complex geological settings and the processes of tectonic evolution. The methods adopted involved the generation of topography/bathymetry, free-air and Bouguer anomaly grids from topography, free-air anomaly and Bouguer anomaly datasets; regional-residual gravity field separation, lineament mapping from the Horizontal Derivative and 2-D modelling of the sub-surface. Within the study area, the elevation ranged from $-4,200$ to $3,840 \mathrm{~m}$. The free-air anomaly map showed a combination of elongated and circular positive free-air anomalies and elongated, negative free-air anomalies whose values varied between $-40 \mathrm{mGal}$ and $70 \mathrm{mGal}$. The Bouguer anomaly values ranged from -121 to $+229 \mathrm{mGal}$. The Bouguer anomaly map also showed both elongated and circular positive and negative Bouguer anomalies. The dominant orientations of the elongated Bouguer anomalies were the NE-SW, the E-W and the ESE-WNW orientations. Gravity modelling within the oceanic region revealed the presence of a basaltic cover whose thickness varied between 1,330 $\mathrm{m}$ to 7,700 $\mathrm{m}$ in the oceanic and continental margin regions. Associated with the occurrence of this basaltic cover were kinks interpreted as eruption fissures from which the basaltic cover was ejected. It was discovered that the African West Coast Atlantic margin consisted of a trench around the continental margin region adjoined just to the north by some high density basalt, and also that the West African Coastline is heavily laced with magmatism and must have therefore been an active magmatic region in the past. Based on the interpreted data, the study concluded that the Equatorial Atlantic Ocean might have opened on a framework of rifts which extended into the inland regions to form the present day sedimentary basins and from the Bouguer anomaly profile along latitude $10^{\circ} \mathrm{N}$ that it is possible that both the Minna batholith and the Jos Plateau exploited the Proterozoic basement weaknesses for their emplacement.
\end{abstract}

\section{Keywords:}

free-air anomaly, Bouguer anomaly, 2-D modelling, basaltic cover, eruption fissure.

\section{Introduction}

Due to the availability of extensive gravity data from the combination of terrestrial and satellite altimetry gravity measurement, free-air and Bouguer anomaly maps and profiles were generated from regional-scaled gravity data with the aim of interpreting gravity anomalies for geologic and tectonic inferences in the Central Equatorial Atlantic region, whose tectonic evolution processes have not been holistically understood (Nnange et al., 2000; Ngako et al., 2008; Balogun et al., 2016).

The study area, which is situated within the "Central Equatorial Atlantic African region", extends from latitude $0^{\circ}$ to $10.0^{\circ} \mathrm{N}$ and from longitude $3.0^{\circ}$ to $15.0^{\circ} \mathrm{E}$ (see Figure 1). The area is comprised of both oceanic and continental regions with the elevation ranging from about $-4,200$ to $4,000 \mathrm{~m}$. The eastern part can be described as a network of plateau having its highest eleva-

Corresponding author: Oluwatimilehin Balogun

balogun.timilehin2015@gmail.com tion as 3,840 $\mathrm{m}$ (at Mountain Cameroon). On the southwestern part is the Atlantic Ocean and the bathymetry in the region approached $-4,000 \mathrm{~m}$. The central part is the coastal sedimentary lowland region which is almost at sea level and the northwestern and the northcentral areas are areas of moderate to high elevation. The regular elevation of the mountains within the area exceeds 1,000 m (see Figure 2).

\subsection{Geology of the study area}

The area covered in this research work includes the Niger Delta, Benue Trough, Nupe Basin, the southwestern Nigeria Shield, part of the North Central Nigeria Shield, the Cameroon Volcanic Line (CVL), the Adamawa Mountain (Cameroon), the Central Africa Shear Zone and the Gabon-Cameroon Shield. The classified geologic map showing some of the tectonic provinces is presented in Figure 3

The study area is characterised by intraplate volcanism such as the one along the Cameroon Volcanic Line 


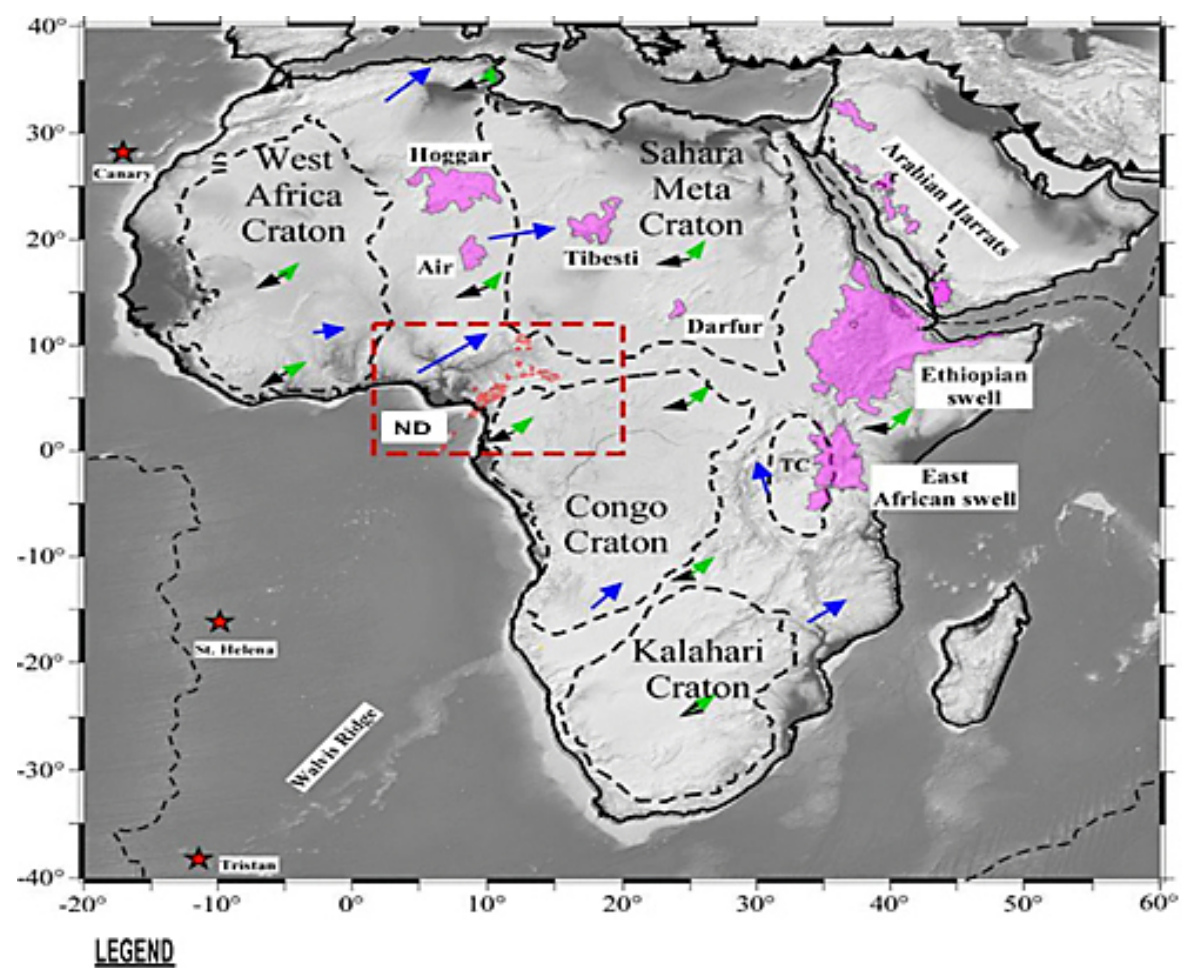

$\rightarrow$ Absolute Plate Motion (APM) Vectors Calculated using the GMHRF Model (Doubrovine atal, 2012)
$\rightarrow$ APMVectors Determined by the HS3-NUVELlA Model (Gripp and Gordon, 2002)
$\rightarrow$ Horizontal Component of Mantle Flow Predicted at $250 \mathrm{~km}$ Depth (Forte et al, 2010)
$\downarrow$ Locations of Atlantic Mantle Plumes (Doubrovine et al, 2012)
L The Study Area
ND Niger Delta

Figure 1: Map of Africa Showing the Study Area, and Major Intraplate Volcanic Centres and Cratons (after Abdelsalam et al., 2011)

(CVL). The CVL and the adjacent areas (which include the entire study area) are tectonically complex regions which include basement shields, mobile belts, shear zones, and regions of active magmatism. Many theories which include the reactivation of ancient suture zones, lithospheric thinning by mantle plumes, and edge-driven mantle convection have been proposed to explain the process of tectonic evolution in these areas (Elsheikh et al., 2014). In addition to the CVL, a notable tectonic feature in the study area is the Benue Trough which is a Mesozoic rift basin that starts from the coast of the Gulf of Guinea and extends transversely as a deep furrow within the Nigerian Shield. It forms part of the West African Mezosoic bifurcating rift system that links other continental rifts in the interior of West African republics of Chad and Niger (Machens, 1973; Burke and Dewey, 1974; Abdelsalam, 2011). It is perceived to be about $1,000 \mathrm{~km}$ long and $300 \mathrm{~km}$ wide (Nwajide, 1990) and has been considered to be a failed arm of a triple plate junction (Hoffman et al., 1974; Olade, 1975; Petters, 1978).

Earlier interpretation of gravity data acquired over the Benue Trough suggested that three prominent events had been recorded in the Benue Trough. These include rift- ing caused by the parting of South America and Africa, volcanism depicted by the axial gravity high along the trough due to presence of volcanic rocks under the sediments and folding marked by gravity low flanking the axial gravity high (Osazuwa, 1987).

The Nupe (Mid-Niger) Basin is another striking intracratonic basin bounded in the Northeast and Southwest by the basement complex while it merges with Anambra and Sokoto basins in sedimentary fill which is comprised of post orogenic molasse facies and a few thin unfolded marine sediments (Adeleye, 1974). From the interpretation of ground Bouguer anomaly data, Ojo and Ajakaiye (1976) proposed that the Nupe Basin was likely created by isotatic subsidence. They however hinted that a rifting origin is also a possibility because the gravity response of the shallow structural features may have been superimposed on the response of the deeper features.

Also covered in the study area is the Benin-Nigeria Shield. This consists of the Nigerian Basement Complex which is located within a Pan-African mobile zone extending between the West African craton in the west and the Gabon-Congo craton in the southeast. Nigeria lies in the central part of the Gondwana portion of the Pangean Supercontinent and remained fairly resistant to denuda- 


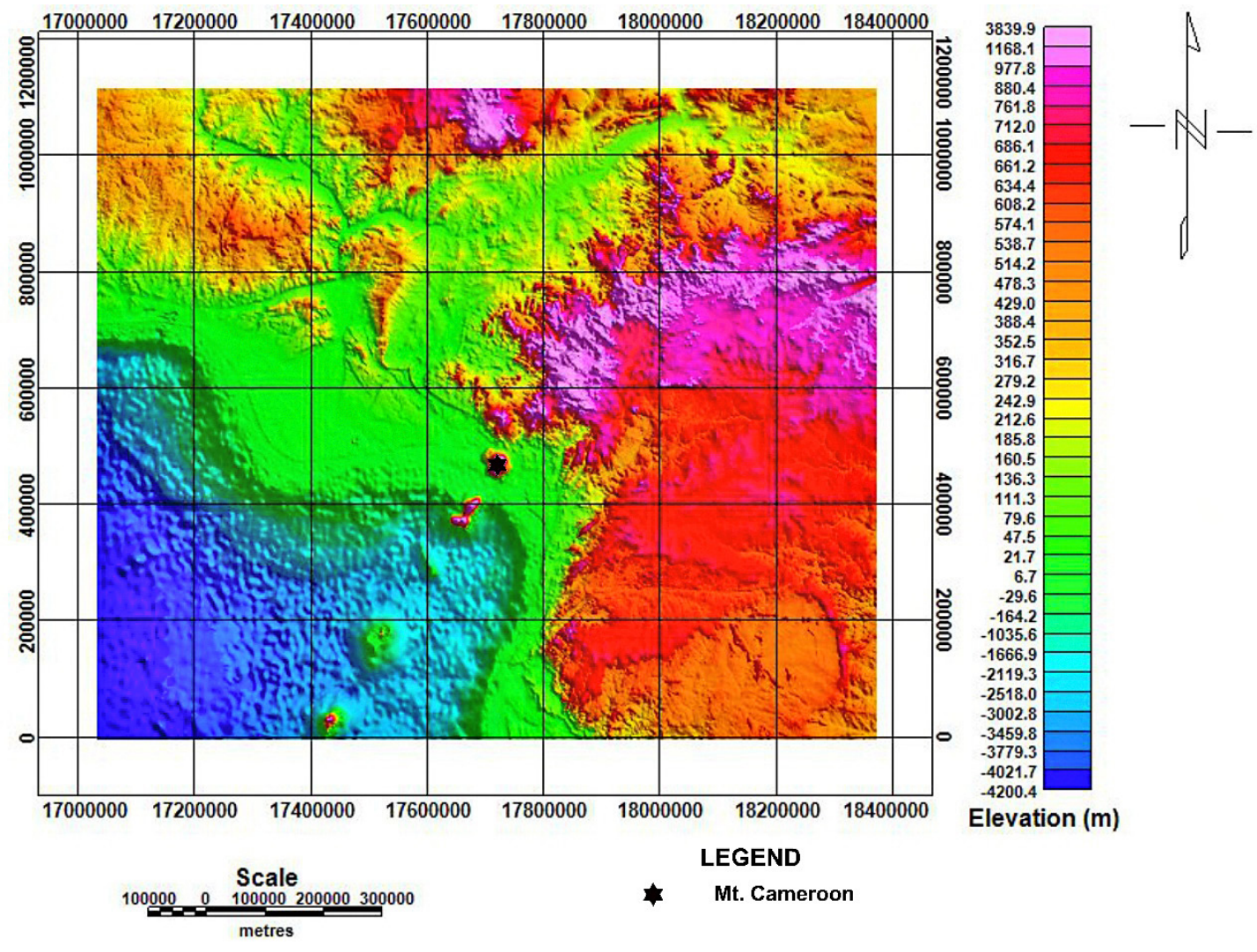

Figure 2: Topography/bathymetry map of the study area

tion (Doust and Omatsola, 1990). The Benin-Nigeria Shield is part of the ancient rocks of the African Shield.

The Adamawa Uplift is another important feature located within the study area. The Adamawa Uplift is a volcanic dome of Tertiary age centred over central Cameroon. It was formed together with other African volcanic uplifts such as the East African Plateau, and is underlain by Precambrian basement rocks, reworked by the Pan-African episode (600 - 500 Ma) and uplifted (1 $\mathrm{km})$ relative to the surrounding area. These rocks which are mainly schists and gneisses intruded by granites and diorites are cut by faults of the Central African Shear Zone (CASZ) (Nnange et al., 2000). The Adamawa Uplift is comprised of the Adamawa Plateau, the Oku Massif, Mount Bambouto and the Manengouba Mountain. The study area is also comprised of the Central African Shear Zone and the Gabon-Cameroon Shield. The Central African Shear Zone is a Megashear zone in Africa extending over about $200 \mathrm{~km}$ from Sudan to Cameroon Ngako et al., 2008). It is believed to have formed during the Pan-African orogenic cycle $(600 \pm 100 \mathrm{Ma})$ during which important tectonic movements occurred giving rise to the Megashear zones in Africa (Ngako et al., 2008)

\section{Materials and Methods}

The dataset used for this study is a combination of terrestrial gravity data and satellite altimetry dataset consisting of global 1 x 1 minute grid free-air anomaly, Bouguer anomaly and Topographic-Bathymetric data compiled from GeoSat (and ERS-1), CyroSat-2 and Jason-1 surveys made available by Scripps Institution of Oceanography, University of California, San Diego, USA and GETECH Africa Gravity Project, Leeds, UK. The study area is bounded by the equator and latitude $10^{\circ} \mathrm{N}$ and longitudes $3^{\circ}$ and $15^{\circ} \mathrm{E}$.

\subsection{Data Resolution}

The data has a resolution of $1 \times 1$ minute grid. This in land units equals to $1.86 \mathrm{~km}$ by $1.84 \mathrm{~km}$. The implication of this is that this dataset can at best only be used for regional studies.

\subsection{The coordinate system adopted}

The 1 x 1 minute grid free-air gravity and topographic-bathymetric data were acquired in degrees but were converted to the WGS-metre coordinate system for easy location of features and distances. The Universal Transverse Mercator (UTM) coordinate system was not adopted because of its zonal dependency. Instead, a more uniform WGS-m coordinate system which is more suited for regional studies was adopted.

\subsection{The Regional-Residual Field Separation}

The regional-residual anomaly separation was carried out using the Upward Continuation Operation which is 


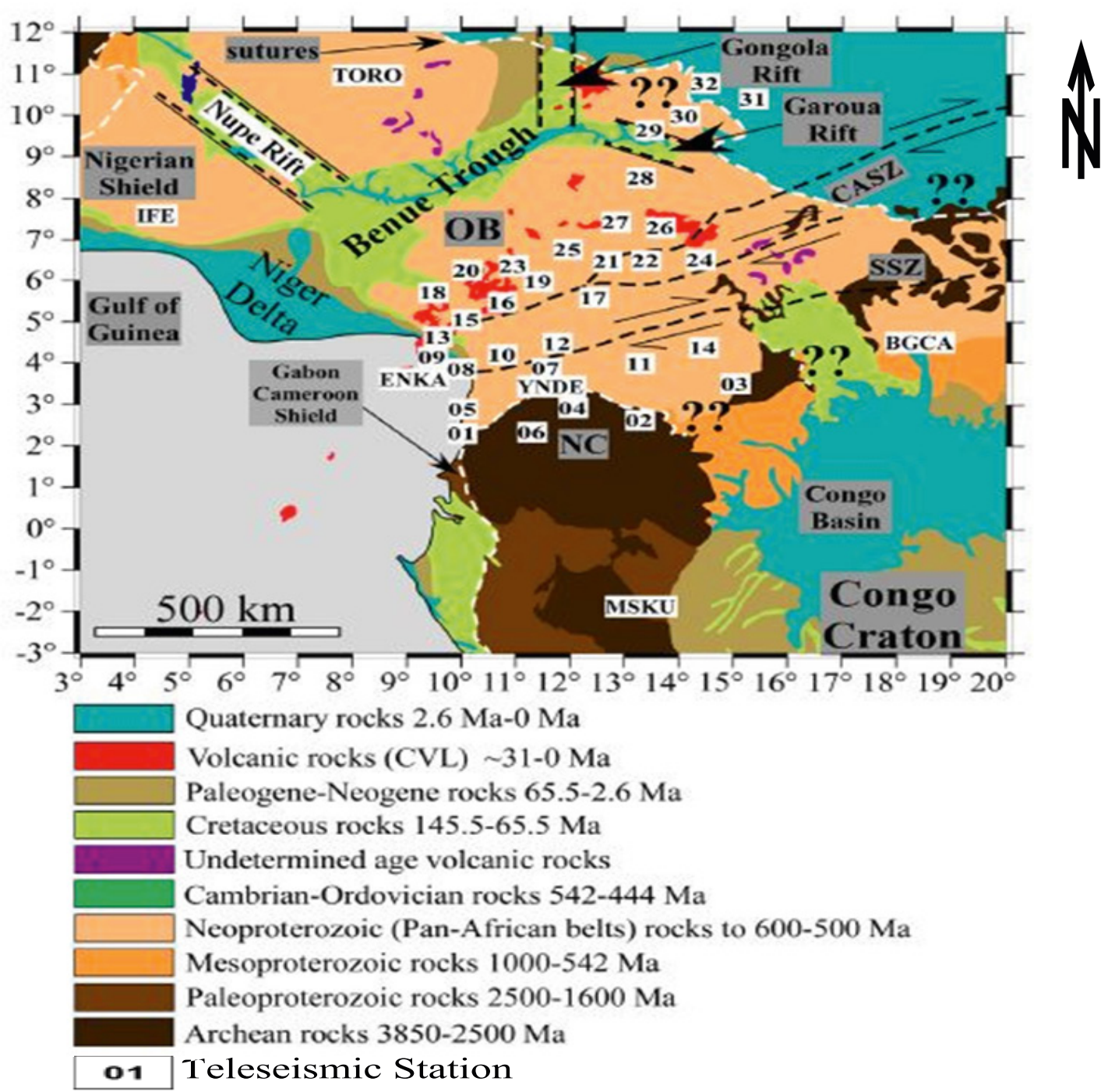

Figure 3: Classified geologic map of the study area (after Elsheilk et al., 2014)

employed in potential field interpretation to determine the form of the variation of the regional field over the survey area. Upward continuation attenuates shallow feature and relatively enhances the anomalies of deeper sources and this makes it applicable for regional-residual separation. When the relatively deeper sources are subtracted from the total field, the resultant is the shallow features (near the field) known as the residual field. The frequency response of upward continuation filter is given in Equation 1 as follows:

$$
\mathrm{F}_{\mathrm{U}}(\mathrm{u}, \mathrm{v}, \mathrm{h})=e^{-2 \lambda h}\left(u^{2}+v^{2}\right)^{1 / 2}
$$

Where:

$\mathrm{h}$ - the height to which the field is continued (m)

$\mathrm{u}$ - equivalent of $\mathrm{x}(\mathrm{m})$ in the frequency domain

$\mathrm{v}$ - equivalent of $\mathrm{y}(\mathrm{m})$ in the frequency domain

This form of continuation effectively suppresses the short wavelength components of a field and smoothens the anomaly. For this research, empirical testing showed that an upward continuation height, $\mathrm{h}$, of 300,000 $\mathrm{m}$ was the optimum source-to-detector height suitable for the separation of the free-air anomaly regional field while $500,000 \mathrm{~m}$ was sufficient for the Bouguer anomaly regional field.

\subsection{Gravity Forward Modelling}

In gravity modelling, the aim is to construct a reasonable geological model whose anomaly honours the observed data. For this research, the GM-SYS ${ }^{\mathrm{TM}}$ module of the Oasis Montaj was used for the modelling exercise. The program compares a theoretical anomaly with successive fit improvement until the best possible fit is accepted. The computational basis for the GM-SYS ${ }^{\mathrm{TM}}$ model response is based on the methods of Talwani et al., (1959) and Talwani and Heirtzler (1964) and makes use of the algorithms described by Won and Bevis (1987). GM-SYS ${ }^{\mathrm{TM}}$ uses a two-dimensional flat-earth model for a potential field that is based on geological 


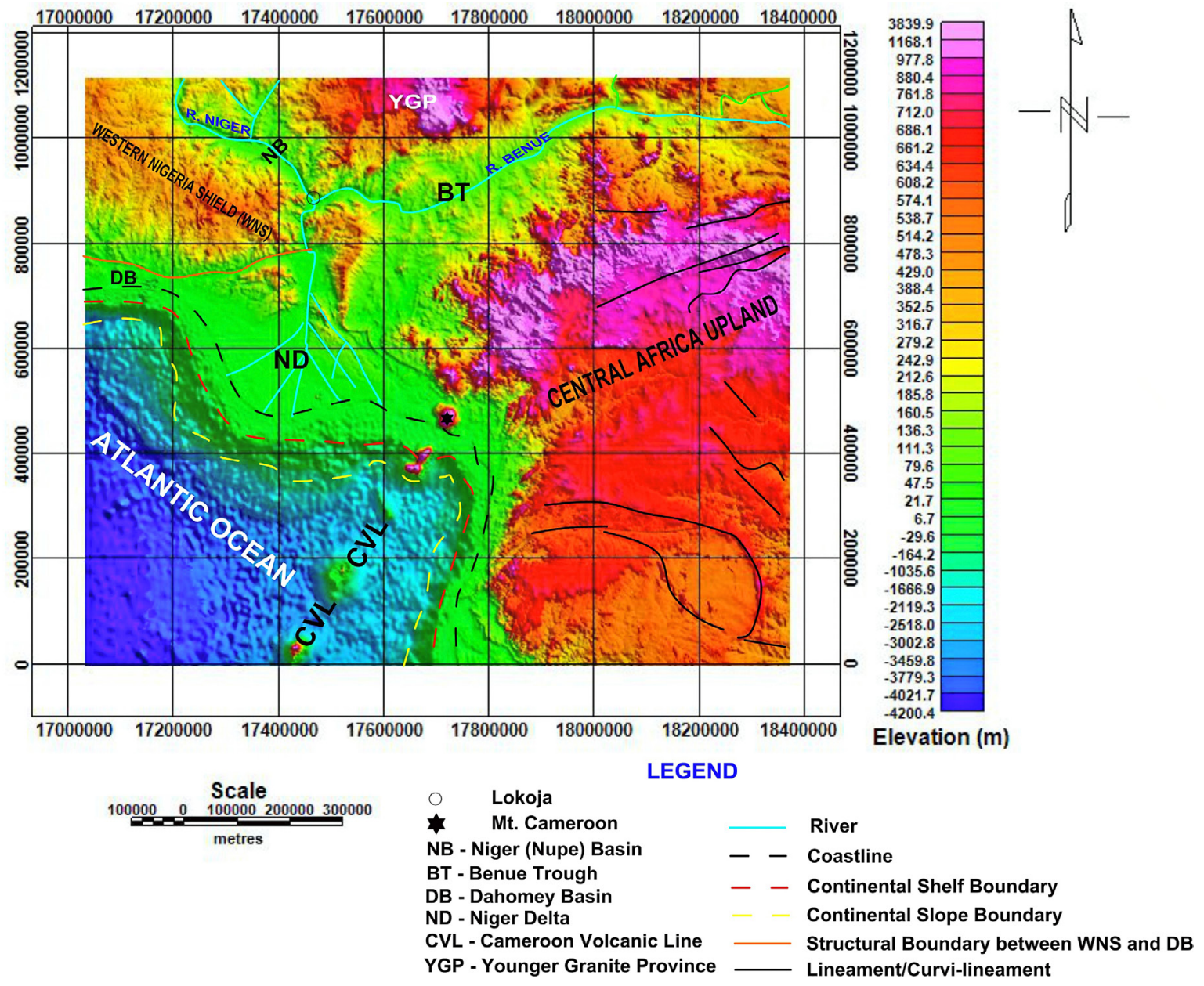

Figure 4: Topography/Bathymetry Map of the Study Area

constraints. The difference between the observed gravity data and calculated gravity response to this model is minimised by reshaping the model or by altering the densities of structural blocks contained within the model until a fit is obtained.

\subsection{Lineament Extraction}

Derivative maps are often generated to identify lineaments which include contacts, joints and faults from potential field data. To map the lineaments within the study area, total horizontal derivative analysis was carried out on the residual gravity data. Horizontal derivative maps are derivative products that reveal the anomaly texture and highlight anomaly pattern discontinuities. According to Hogg (2004), horizontal derivatives do provide better resolution and greater accuracy at wider line spacing. It is essentially important while trying to map linear features such as fault zones and/or dykes from potential field data.

Derivatives tend to enhance near surface features by increasing the power of linear dimensions in the denominator (i.e. distance) because the gravity effect varies inversely as the square of the distance (Telford et al.,
1990). The total horizontal gradient magnitude of gravity field (THGM) is given in Equation 2 as follows:

$$
\mathrm{THGM}=\sqrt{\left(-\frac{\partial g}{\partial x}\right)^{2}+\left(-\frac{\partial g}{\partial y}\right)^{2}}
$$

Where:

$$
\begin{aligned}
& \left(-\frac{\partial g}{\partial x}\right)^{2}-\underset{(\mathrm{mGal} / \mathrm{m})}{\text { change in the gravity field in the } \mathrm{x} \text { direction }} \\
& \left(-\frac{\partial g}{\partial y}\right)^{2}-\begin{array}{c}
\text { change in the gravity field in the y direction } \\
(\mathrm{mGal} / \mathrm{m})
\end{array}
\end{aligned}
$$

This function peaks over contacts on the assumption that the regional gravity field and gravity source are vertical. The ridges or maxima of the horizontal derivatives are recognized generally as being good locators of shallow, vertical body edges. According to Philips (2000), the horizontal derivative method will produce apparent contacts that are linear and very continuous. The apparent contacts will commonly be shifted towards the down dip direction for dipping contact sources. 


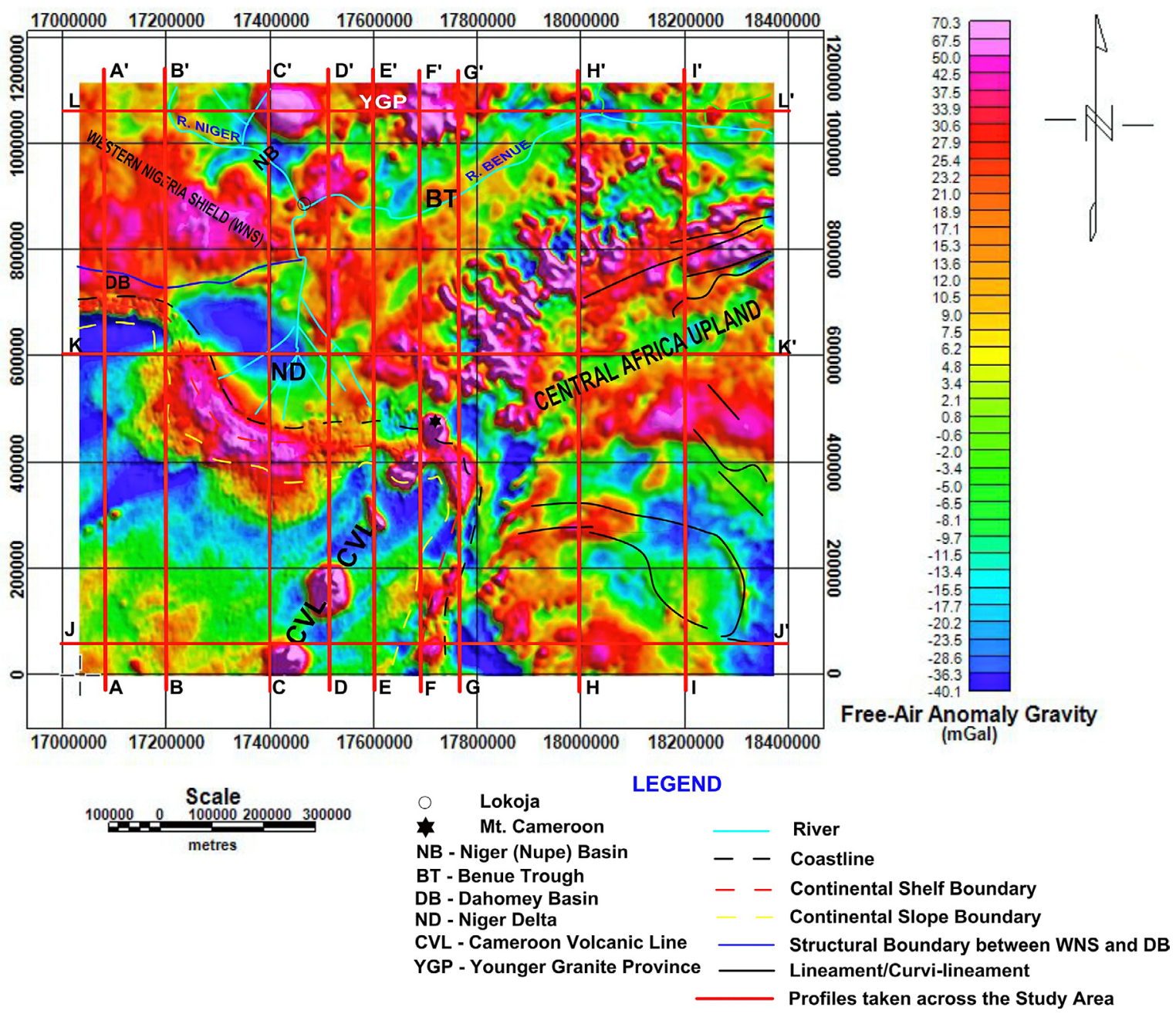

Figure 5: Free-air Anomaly Map of the Study Area

\section{Results and Discussion}

\subsection{The Relief, Free-air and Bouguer Anomaly Maps}

The relief, free-air and Bouguer anomaly maps are shown in Figures 4, 5 and 6 respectively.

\subsubsection{The Relief (Topography and Bathymetry) Map}

As can be observed from Figure 4, the highest elevation within the area is $3840 \mathrm{~m}$ (at Mt. Cameroon) and the deepest bathymetry is $-4200 \mathrm{~m}$ at the southwestern end. The average elevation of mountains and plateau found within the area is approximately $1500 \mathrm{~m}$.

The area is comprised of both basement complex and sedimentary terrains. The basement complex terrains were noted to have relatively higher elevations than the adjacent sedimentary terrains. Major basement complex terrains in the area are the Western Nigeria Shield (WNS), the Younger Granite Province (YGP) and the Central Africa upland. The sedimentary terrains include the Niger (Nupe) Basin, Benue Trough, Dahomey Basin and the Niger Delta. The Niger Delta is a coastal sedimentary lowland.

The study area is drained by two major rivers (the Niger River and the Benue River) which both meet at Lokoja, Nigeria to form a confluence before flowing southwards to enter into the Atlantic Ocean with many mouths at the Niger Delta. As we move towards the Atlantic Ocean, from the coastline are the distinctively defined continental shelf and continental slope whose boundaries have been indicated in Figure 4. The ocean bathymetry slopes gently in the southwestern direction at $1.6 \%\left(0.92^{\circ}\right)$. The oceanic section of the Cameroon Volcanic Line which is made up of some islands (which include Sao Tome, Principe and Bioko) is also noticeable at the central southern region. The Central Africa upland, covering the eastern section of the study area, was observed to have noticeable linear structures which are likely to be planes of weaknesses identified as lineaments in Figure 4.

The occurrence of coastal sedimentary lowland adjoining the Atlantic Ocean in the Gulf of Guinea to the 


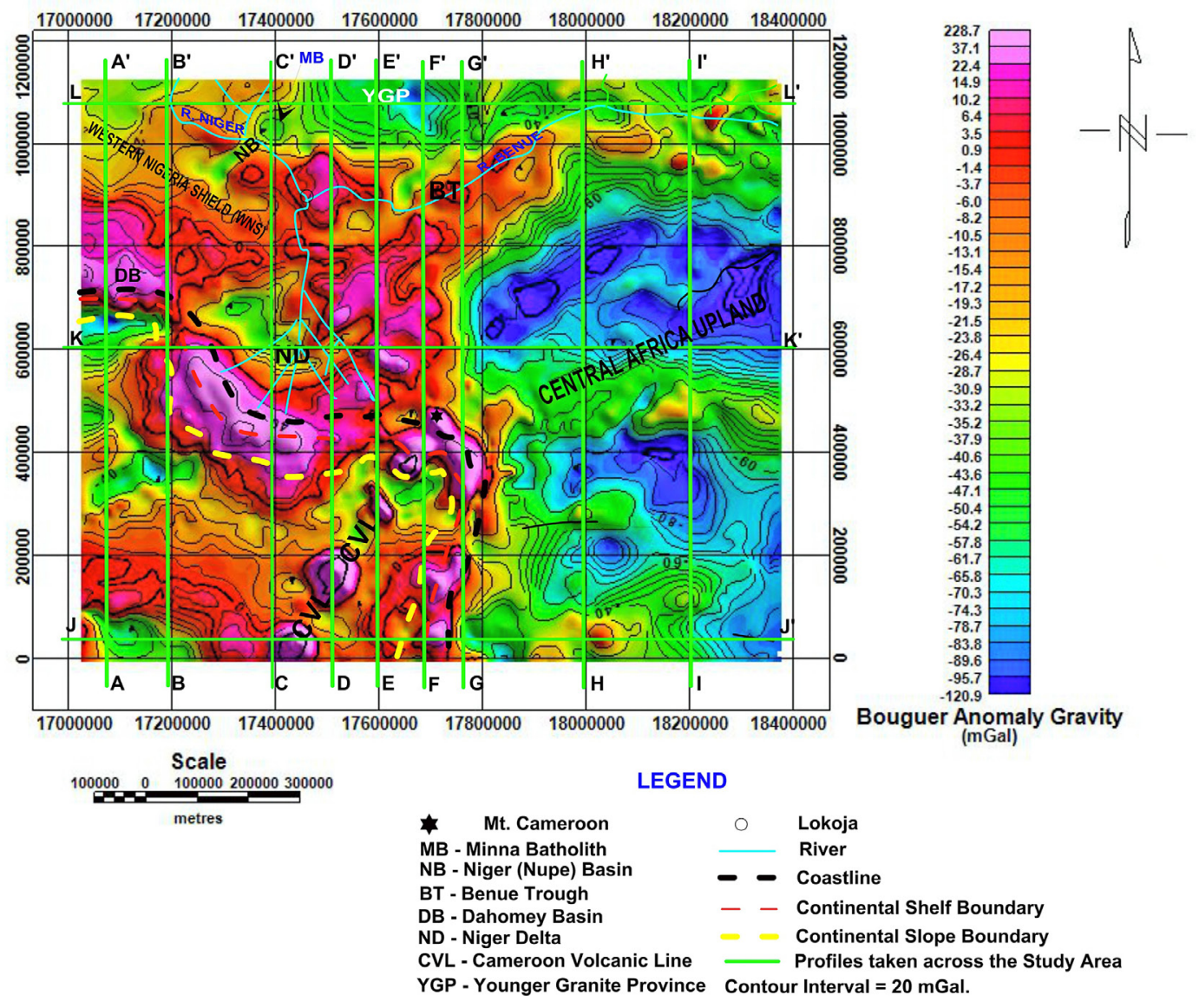

Figure 6: Bouguer Anomaly Map of the Study Area

south and upland regions to the east and north suggests that the area is a passive sedimentary region with history of rifting, subsidence and tectonism.

\subsubsection{The Free-air Anomaly Map}

The free-air anomaly map (see Figure 5) shows a combination of elongated and circular positive free-air anomalies and elongated, negative free-air anomalies. Free-air anomaly values ranged between -40 and $70 \mathrm{mGal}$.

Conspicuous signatures that were identified on the free-air anomaly map include: a strongly positive freeair gravity anomaly whose shape (signature) is the same as the outline of the coastline, continental shelf and continental slope in the region of the coastline as we move towards the Atlantic Ocean; a large, strongly negative free-air gravity anomaly in the western part of the Niger Delta corresponding to area of thick sediment loading; a well-defined free-air anomaly gravity low within the Niger (Nupe) Basin; a circular, free-air anomaly gravity high corresponding to the islands of the oceanic section of the Cameroon Volcanic Line; and a free-air anomaly gravity high corresponding to the basement complex provinces of the Western Nigeria Shield, Younger Granite Province and the northern section of the Central Africa upland.
A mid-basin gravity high within the Benue Trough is also noticeable. This mid-basin gravity high was observed to lie directly under the Benue River in the middle section of the trough. Osazuwa (1978) delineated this anomaly in the centre of the Benue Trough (around the middle to upper section) and called it "axial gravity high". Within the study area, circular positive free-air anomalies seemed to be characteristic of volcanic emplacements.

The positive free-air anomaly gravity found to outline the coastline, continental shelf and continental slope regions suggest that the coastline region is preferentially laced with magmatism.

\subsubsection{The Bouguer Anomaly Map}

Figure 6 is the Bouguer anomaly map of the study area. The Bouguer anomaly values varied from -121 to $+229 \mathrm{mGal}$. The Atlantic Ocean region of the southwestern portion is characterised by negative Bouguer anomaly values (with values ranging from -80 to $0 \mathrm{mGal}$ ). The eastern region which is purely a continental area is also characterised by negative Bouguer anomaly values though with greater amplitude (Bouguer anomaly values ranged from -30 to $-100 \mathrm{mGal})$. The central western region corresponds with the oceanic crust of the Niger 

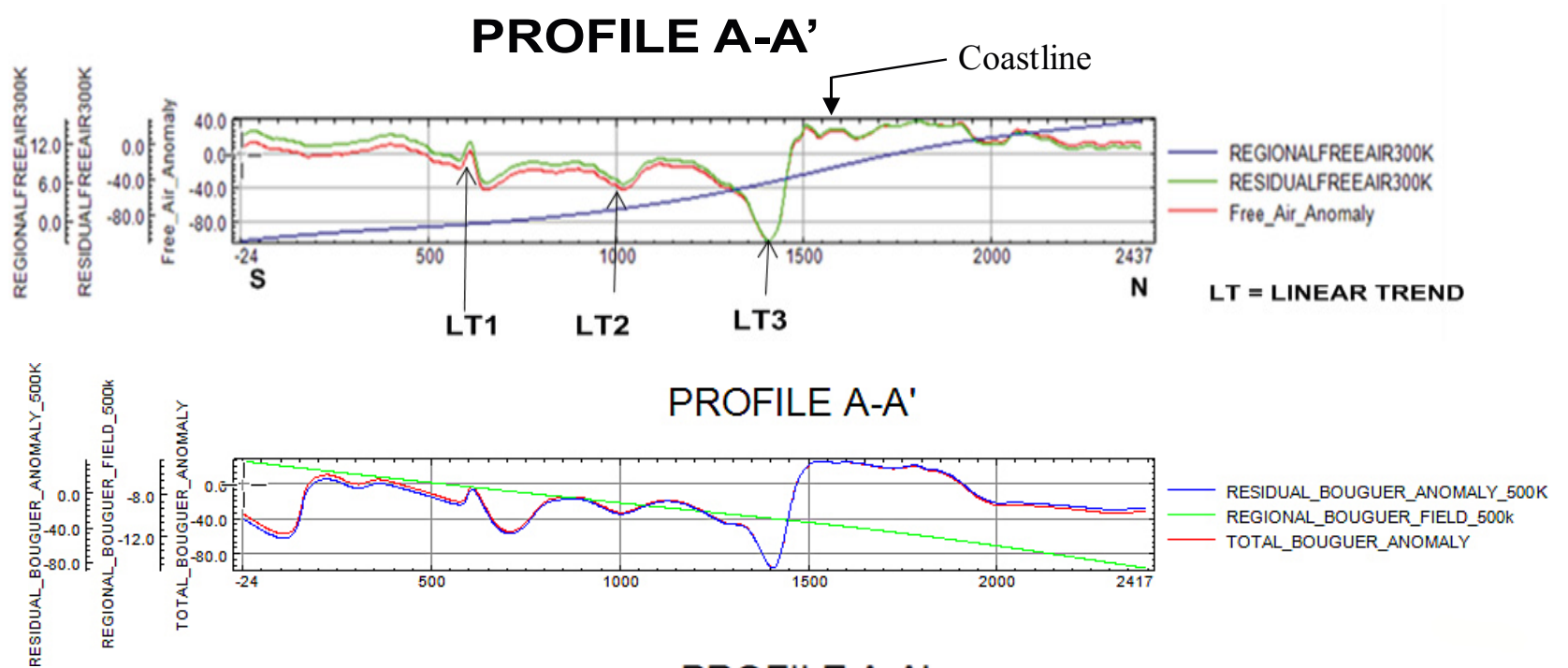

PROFILE A-A'

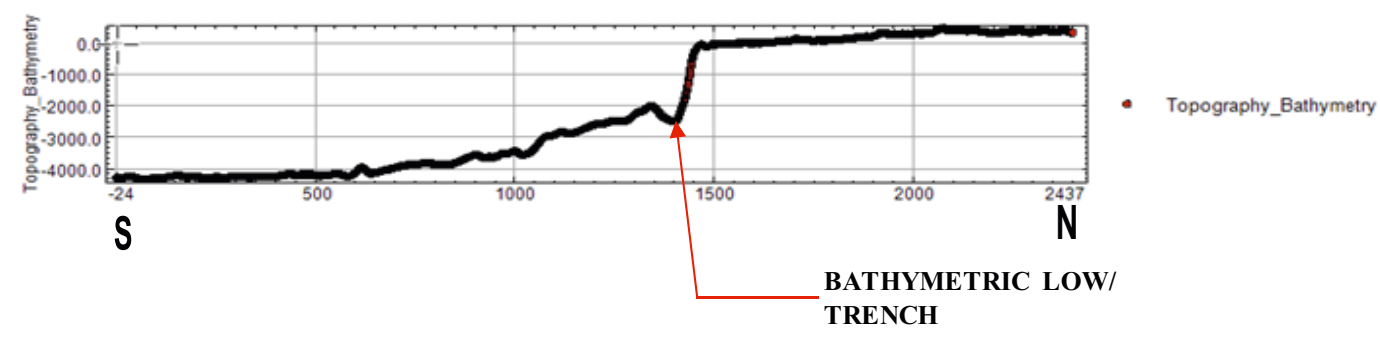

Figure 7(a): Free-air, Bouguer and Topographic/Bathymetric Profiles along 17,077,351 mE (i.e. longitude $3 \cdot 41^{\circ} \mathrm{E}$ )

Delta and has positive anomaly values which ranged between +10 and $+50 \mathrm{mGal}$. The northwestern section has a combination of moderately positive and negative Bouguer anomaly values.

The anomalies are mostly elongated and trend in the E-W, NE-SW or ESE-WNW direction though there are some other conspicuous anomalies which appear rather more circular than elongated. The positive circular anomalies are preferentially located within the oceanic region and coincide with the oceanic section of the Cameroon Volcanic Line while the negative circular anomalies are on the continent and are found to be associated with the Minna batholith and the Younger Granite Province. The elongated negative anomalies appear more profound in the eastern region of the area which is dominated by an abundance of plateau and shear zones.

\subsection{Free-air and Bouguer Anomaly Profiles}

For a more detailed interpretation of the study area, profiles were taken in the East-West and North-South directions and were interpreted. The manner at which the profiles were taken over the study area is illustrated in Figures 5 and 6. Figures 7(a)-(l) are the generated topographic, free-air and Bouguer anomaly profiles.

\subsubsection{Profile A-A' - Figure $7(a)$}

The southern part of the profile falls within the Equatorial Atlantic Ocean while the northern part falls within the continental area. Both the free-air and Bouguer anomaly profiles, to a large extent, mimic the topography. There are three small but noticeable discrete kinks (labelled LT1, LT2 and LT3) observable on the topography/bathymetry, Bouguer and free-air profiles in the oceanic region. The fact that the discrete anomaly patterns were also observable on a more easterly Profile B-B', showed that the kinks themselves were continuous over the oceanic region.

More conspicuously, there is also a notable free-air anomaly high north of the "LT3" low, resulting in a "lowhigh" (-103/+34 mGal) pair free-air anomaly with "LT3" at the shelf-edge. This "low-high" signature is also noticeable on the Bouguer anomaly profile and can as well be observed on the topography/bathymetry profile.

The kinks observed (which were described as LTs) are usually relics of rifting often associated with the formation of a passive basin margin. The section between LT1 and LT3 is likely to have developed from the widening of the passive basin margin due to continuity in divergent plate motions and consequently the accretion of oceanic crust (drifting stage). Being a region that is relatively far from the spreading centre, significant sediment deposition is expected over LT1, LT2 and LT3 with continuous ocean spreading facilitating the infilling of the LTs with sediments. This would then explain the reason for the negative Bouguer gravity anomaly associated with the region of the LTs. 


\section{PROFILE B-B'}
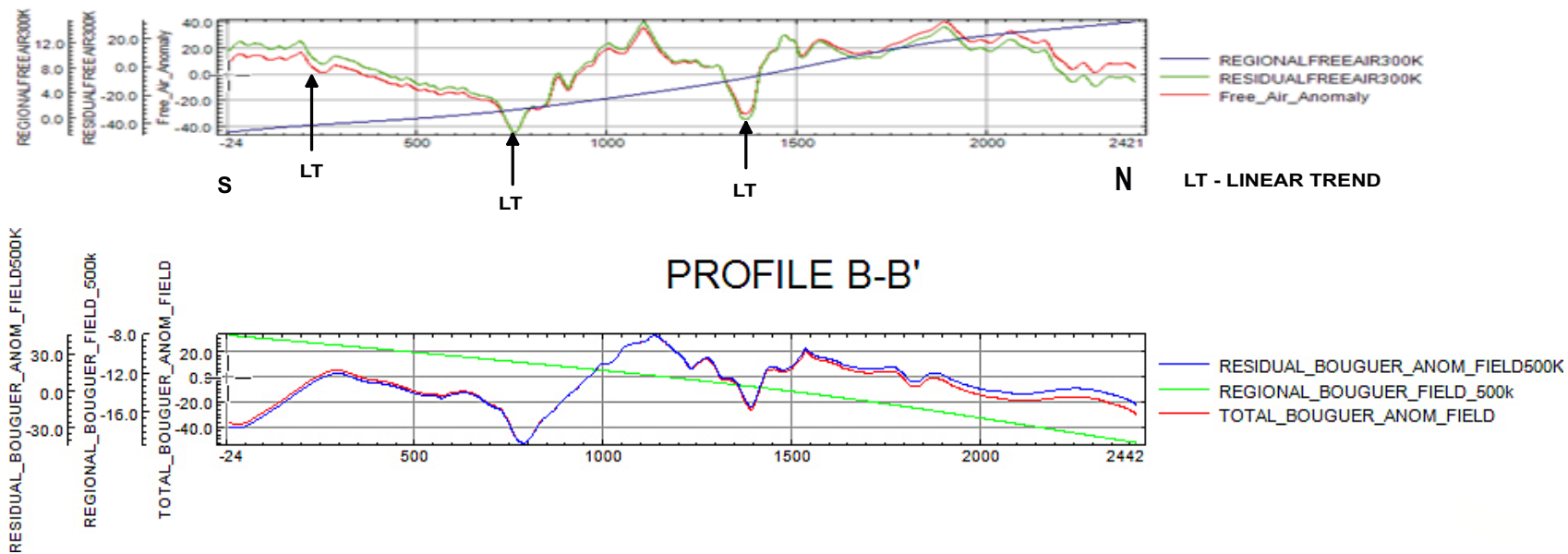

PROFILE B-B'

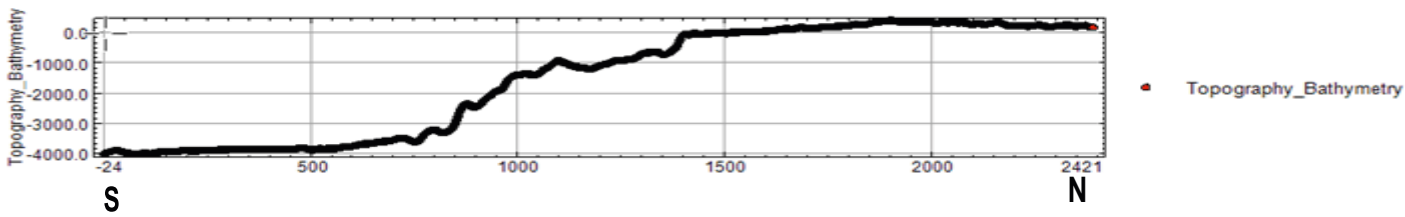

Figure 7(b): Free-air, Bouguer and Topographic/Bathymetric Profiles along 17,200,00o $\mathrm{mE}$ (i.e. longitude $4 \cdot 51^{\circ} \mathrm{E}$ )

Due to the mildly to strongly positive free-air and Bouguer gravity anomalies noted around the coastline, continental shelf and continental slope on the free-air and Bouguer gravity anomaly maps and the association of such signature with volcanism such as the Cameroon Mountain and Cameroon Volcanic Line (see Figures 5 and 6), it will be reasonable to suggest that the region around the coastline is heavily laced with magmatism (intrusive volcanism). The gravity high adjoining LT3 to its immediate north (Figure 7(a)) was interpreted as evidence of magmatism around the continental margin.

Since the gravity anomalies observed around the continental margin are strong, it is expected that the causative underlying rock is very dense. It should be noted that Atlantic continental margins have been known to be associated with the presence of high density basalt from drilling experience (Ramirez, 1995). Similarly, the islands of the oceanic section of the Cameroon Volcanic Line, consisting of Sao-Tome, Santo Antonio Island, Bioko, Malabo, etc. which are within the study area, are known to be underlain by high density basalts.

\subsubsection{Profile B-B' - Figure $7(\mathbf{b})$}

The southern part of the profile falls within the Equatorial Atlantic Ocean while the northern part falls within the continental area. There are also a series of noticeable kinks, designated as (LTs) as well, within the oceanic part. Due to the fact that the kinks seem to continue to appear (in a discrete manner) as we move towards the coastline (since it was first imaged on the more westerly Profile A-A'), it can be said that the kinks continued over the approximately E-W spreading seafloor which is being driven by the proximal, approximately N-S trending oceanic ridge.

However, the shift in position of the kinks on Profile A-A' in comparison to kinks on Profile B-B' (relative to the N-S direction) suggests a N-S displacement of the kinks relative to one another as we move eastwards (see Figures 7(a) and 7(b)). Considering the fact that the region is a region proximal to a mid ocean ridge and therefore a region associated with seafloor spreading, the relative N-S displacement of the kinks would then suggest the likelihood of "transform plate motion" in the approximate N-S direction in the region. This would explain the relative N-S displacement of the kinks. Such kinks and displaced fissures over spreading seafloor regions have usually been associated with transform plate motion (Fairhead and Wilson, 2005).

There is also a noticeable "low-high" pair free-air and Bouguer anomaly (of amplitude $-46 /+30 \mathrm{mGal}$ and $-52 /+33 \mathrm{mGal}$ respectively) at the shelf-edge just as was observed on Profile A-A'. The "low" is interpreted to be due to a continental margin trench and the "high", due to the presence of high density basalts related to the Island of the Cameroon Volcanic Line in the shelf region.

\subsubsection{Profile C-C' - Figure $7(\mathbf{c})$}

The southern end consists of the oceanic part and the continental margin. The northern part is within the continental area. The southernmost part (labelled A on the profile) is the westernmost edge of Sao-Tome Island. The portion labelled B shows a "low-high" (-17/+50 

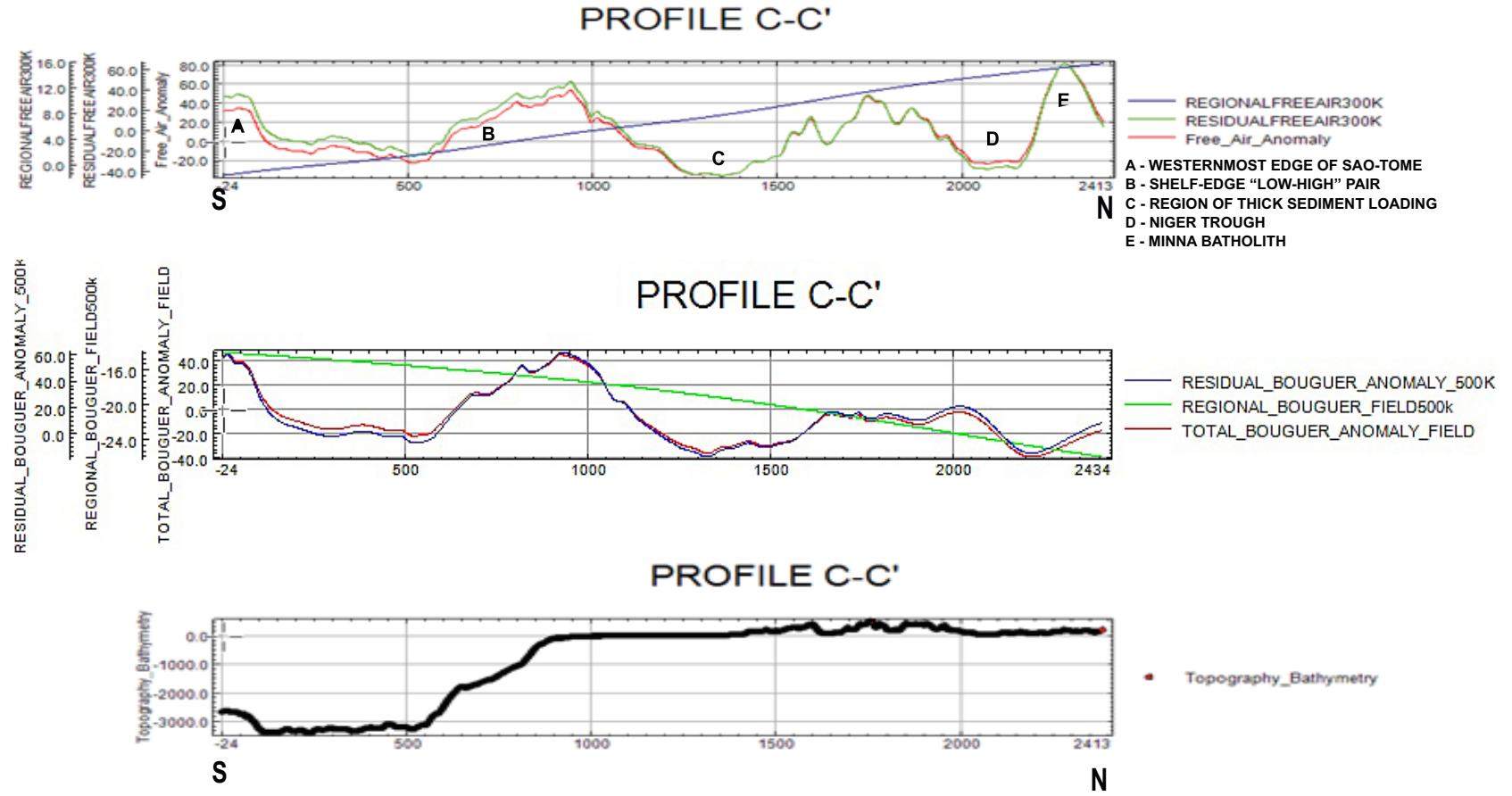

Figure 7 (c): Free-air, Bouguer and Topographic/Bathymetric Profiles along 17,400,0oo mE (i.e. longitude 6.30 ${ }^{\circ} \mathrm{E}$ )

mGal) pair free-air anomaly at the shelf-edge. This means that the high density basalt is also likely present in the region of the continental shelf. The portion labelled was interpreted to be an area of thick sediment loading. It corresponds with parts of the Niger Delta and portion D is the Mid-Niger (Nupe) Trough. The edges of the rift of the trough were vividly seen on the free-air anomaly profile. The portion labelled E is the Minna batholith (see Figure 7(c)).

\subsubsection{Profile D-D' - Figure $7(\mathbf{d})$}

The only prominent anomaly in this profile is the Santo-Antonio Island (labelled A) located within the oceanic section. This island is part of the oceanic section of the Cameroon Volcanic Line (CVL). The island is likely to be underlain by high density basalt. High density basalts are also likely present at the shelf edge.

\subsubsection{Profile E-E' - Figure $7(\mathbf{e})$}

This profile runs over the Bioko Island, Oban Massif, on the eastern edge of the Abakaliki anticlinorium, lower Benue Trough and terminates on the parts of the Nigerian Younger Granite Province. There is a low-high" $(-10 /+45 \mathrm{mGal})$ pair free-air anomaly at the shelf-edge as well (the area labelled B).

\subsubsection{Profile F-F' - Figure $\mathbf{7}(\mathbf{f})$}

This profile runs over Malabo (Equatorial Guinea), the middle Benue Trough and part of the Jos Plateau. The free-air anomaly profile suggests that though the Benue Trough may have been adjoined by several other basins and characterised with various geological structures, its southern rift margin could be located as far as the northern boundary of Malabo and its northern rift margin at its boundary with the part of Jos Plateau cut by the profile. The part labelled $\mathrm{C}$ on the profile corresponds with a location, $23 \mathrm{~km}$ East of Barakin Sauki, Plateau state, Nigeria. It is part of the Nigerian Younger Granite Province.

\subsubsection{Profile G-G' - Figure $7(\mathrm{~g})$}

This profile runs over the westernmost part of Adamawa Uplift, Benue Trough and terminates on the Jos plateau. The free-air anomaly profile along this line also suggests that the southern rift of the Benue Trough on this line is likely to be located at the northern boundary of the westernmost part of the Adamawa Uplift and its northern rift margin is at the boundary with Jos Plateau cut by the profile.

\subsubsection{Profile H-H' - Figure $\mathbf{7}(\mathbf{h})$}

This profile covers an entirely continental region. It runs over the Cameroon Mantle Plume (CMP), the upper end of the Benue Trough and the Biu volcano. The intense volcanic activity (wiggle anomaly) around the Northern end of the profile may have been influenced by the proximity of the region to the CMP.

\subsubsection{Profile I-I' - Figure $7(\mathbf{i})$}

This profile also covers an entirely continental region. It runs over the Adamawa Uplift and the Garoua Rift. The formation of the Adamawa Uplift may also have been due to its proximity to the CMP. 

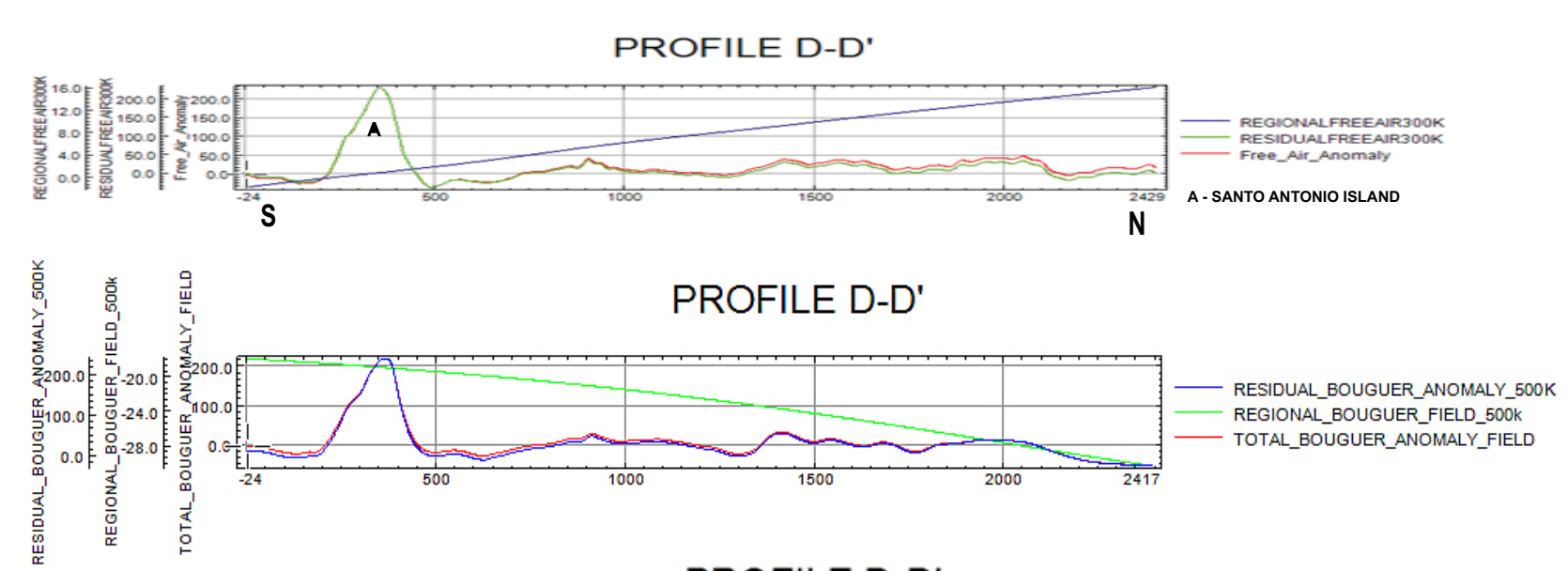

PROFILE D-D'

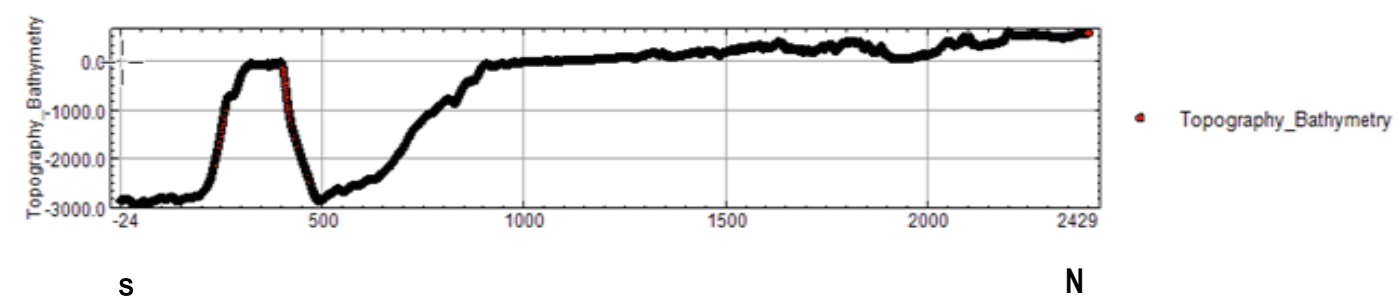

Figure $7(\mathbf{d})$ : Free-air, Bouguer and Topographic/Bathymetric Profiles along 17,512,ooo mE (i.e. longitude 7.3 ${ }^{\circ} \mathrm{E}$

PROFILE E-E'

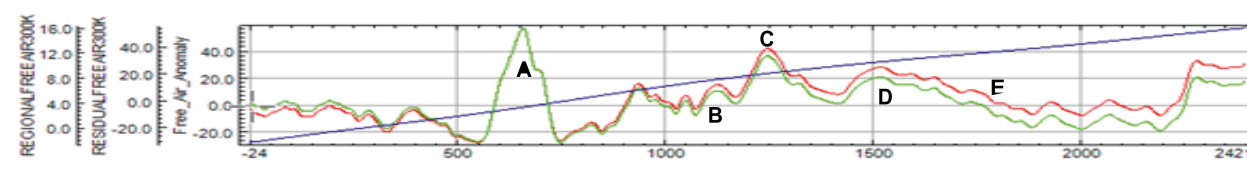

REGIONALLFEEAIR300K
RESIDUALFREEAIR300K
Free_Air_AnOMaly

A - BIOKO ISLAN_AnOmaly
B - SHELF-EDGE "LOW-HIGH" PAIR

C - OBAN MASSIF

$\mathrm{S}$

N D - LOWER BENUE TROUGH

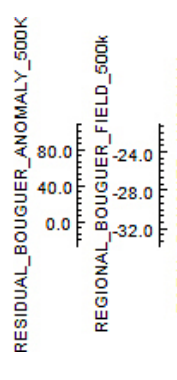

PROFILE E-E'

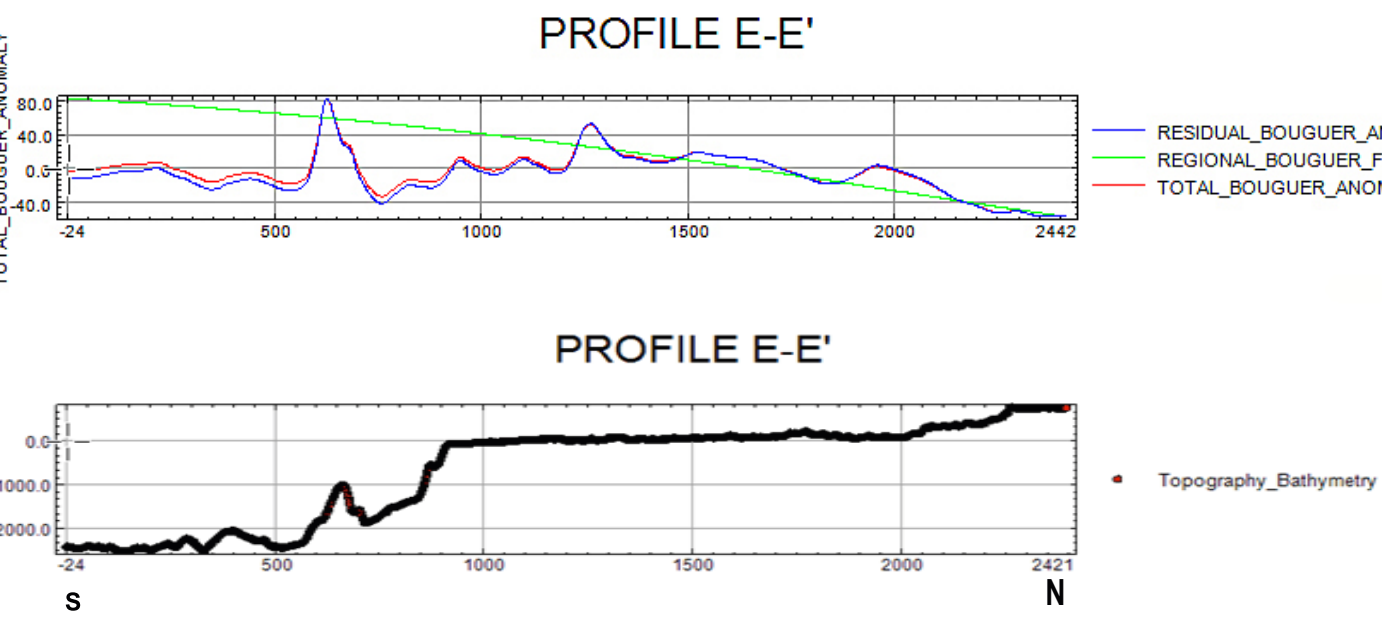

Figure 7(e): Free-air, Bouguer and Topographic/Bathymetric Profiles along 17,60o,ooo mE (i.e. longitude 8.1 ${ }^{\circ}$ )

\subsubsection{Profile J-J' - Figure $7(\mathbf{j})$}

This is a West-East running profile, with an ocean in the western part and a continental eastern part. The only prominent anomaly on this profile is the Sao-Tome Island of the CVL. The regional trends (at 300,000 m wavelength for the free-air anomaly profile and at
$500,000 \mathrm{~m}$ wavelength for the Bouguer anomaly profile) were not adequate on this profile, especially in the western end. This suggests that under this region there is likely to be a massive body of intermediate wavelength. Due to its location, this massive body is likely to be a mantle upwelling which could be part of the African superplume. 
PROFILE F-F'
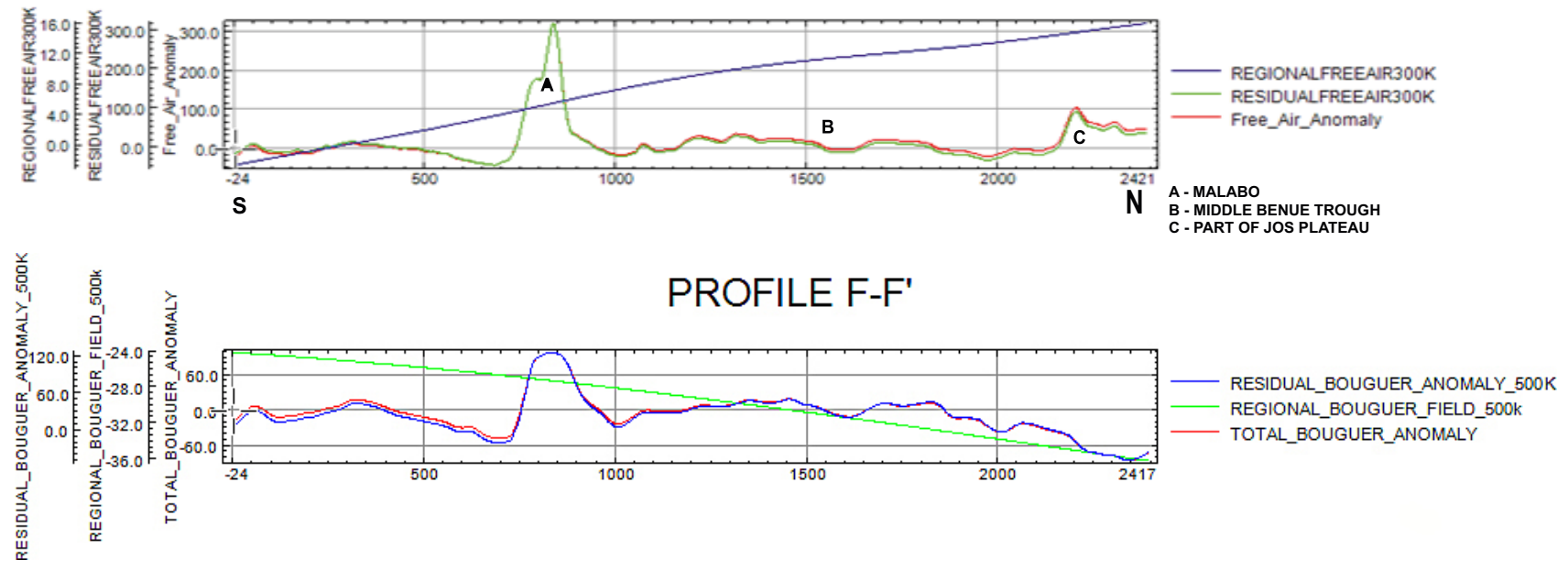

PROFILE F-F'

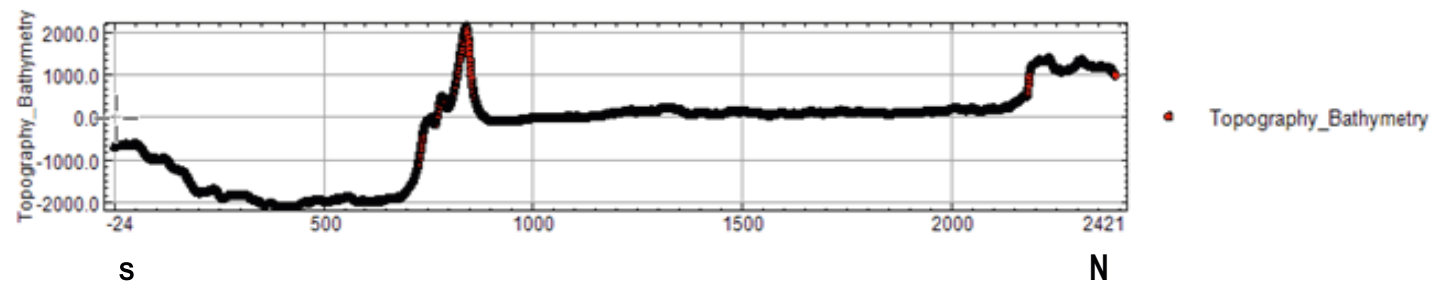

Figure 7(f): Free-air, Bouguer and Topographic/Bathymetric Profiles along 17,670,ooo mE (i.e. longitude 8.73 ${ }^{\circ} \mathrm{E}$ )

PROFILE G-G'
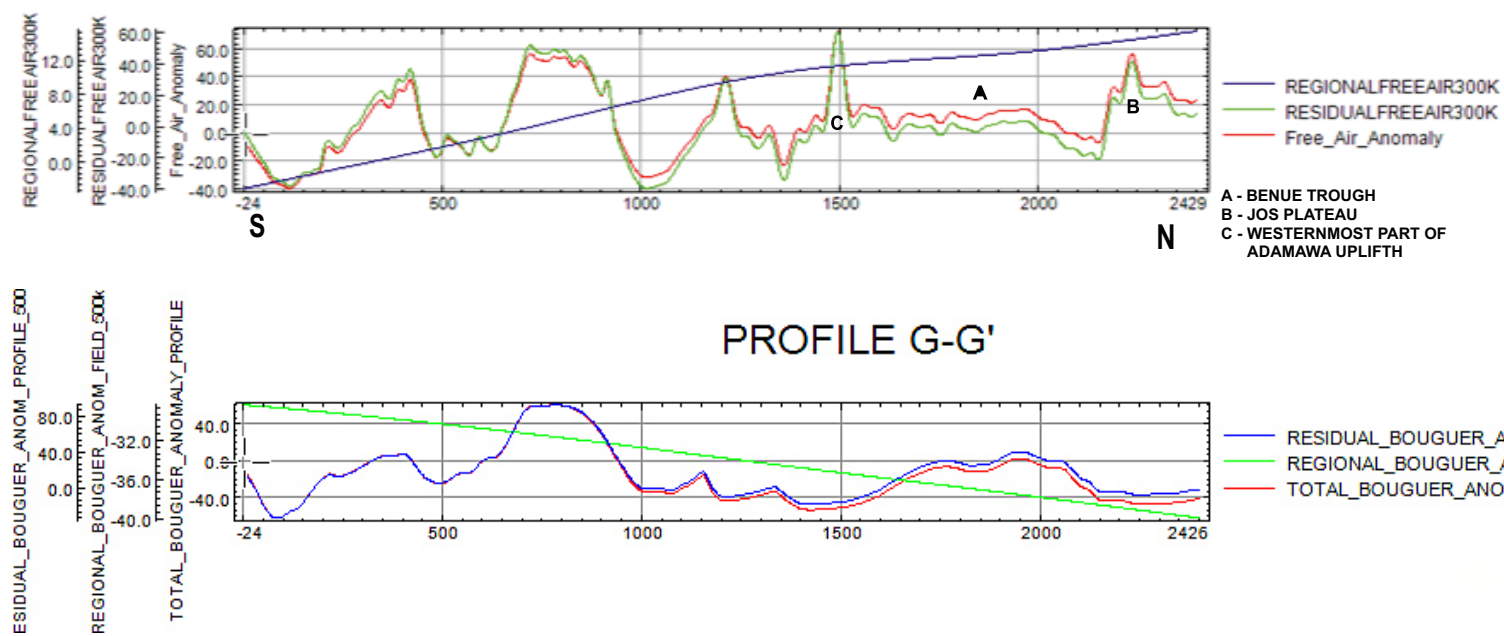

- RESIDUAL_BOUGUER_ANOM_PROFILE_500K REGIONAL_BOUGUER_ANOM_FIELD_500 TOTAL_BOUGUER_ANOMALY_PROFILE

PROFILE G-G'

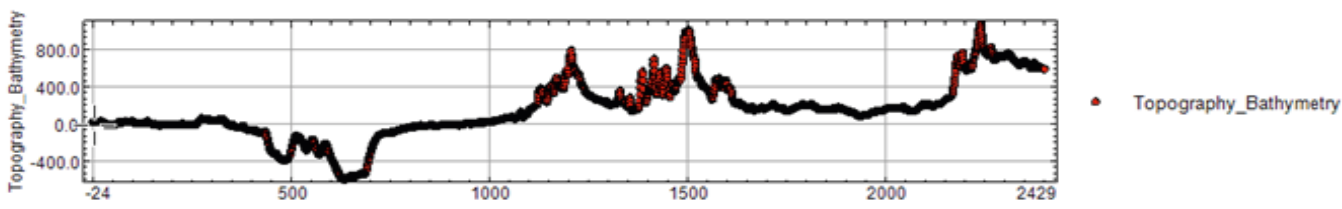

S

N

Figure 7(g): Free-air, Bouguer and Topographic/Bathymetric Profiles along 17,770,ooo mE (i.e. longitude 9.54 ${ }^{\circ} \mathrm{E}$ ) 


\section{PROFILE H-H'}
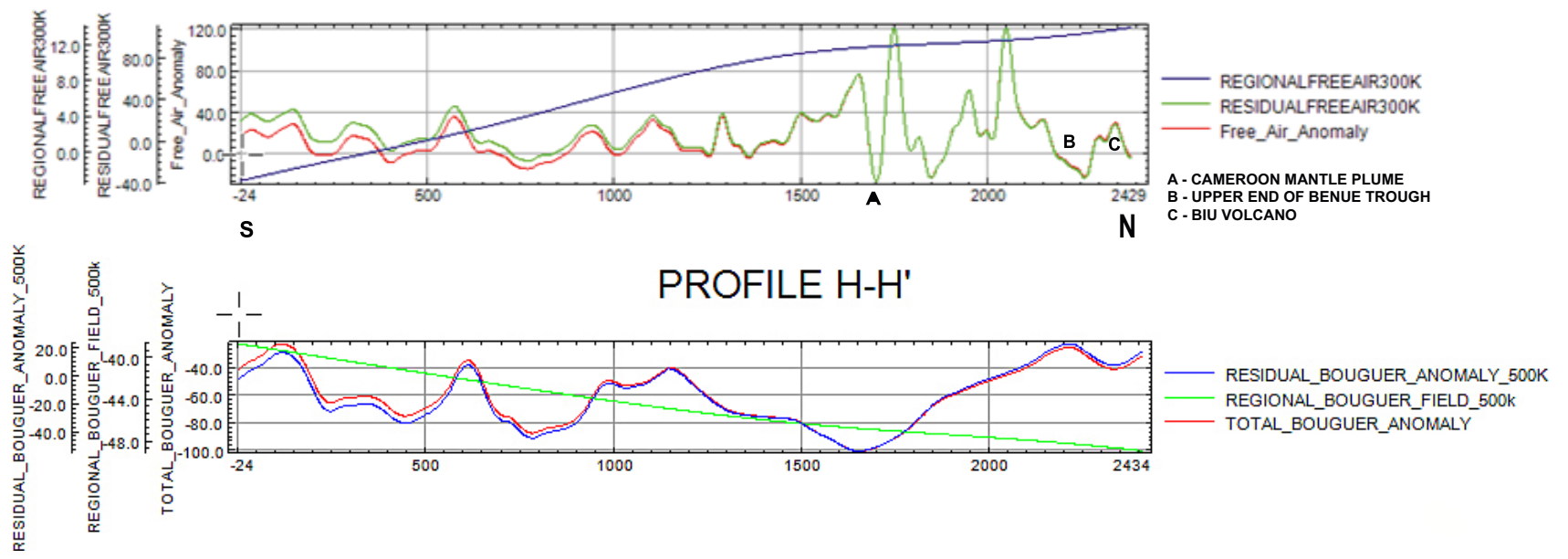

PROFILE H-H'

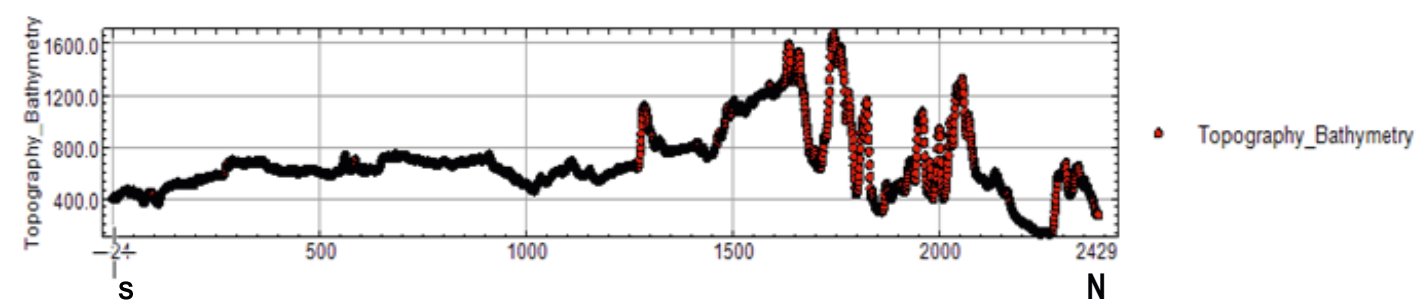

Figure $7(\mathbf{h})$ : Free-air, Bouguer and Topographic/Bathymetric Profiles along 18,ooo,ooo mE (i.e. longitude 11. $7^{\circ} \mathrm{E}$ )

PROFILE I-I'
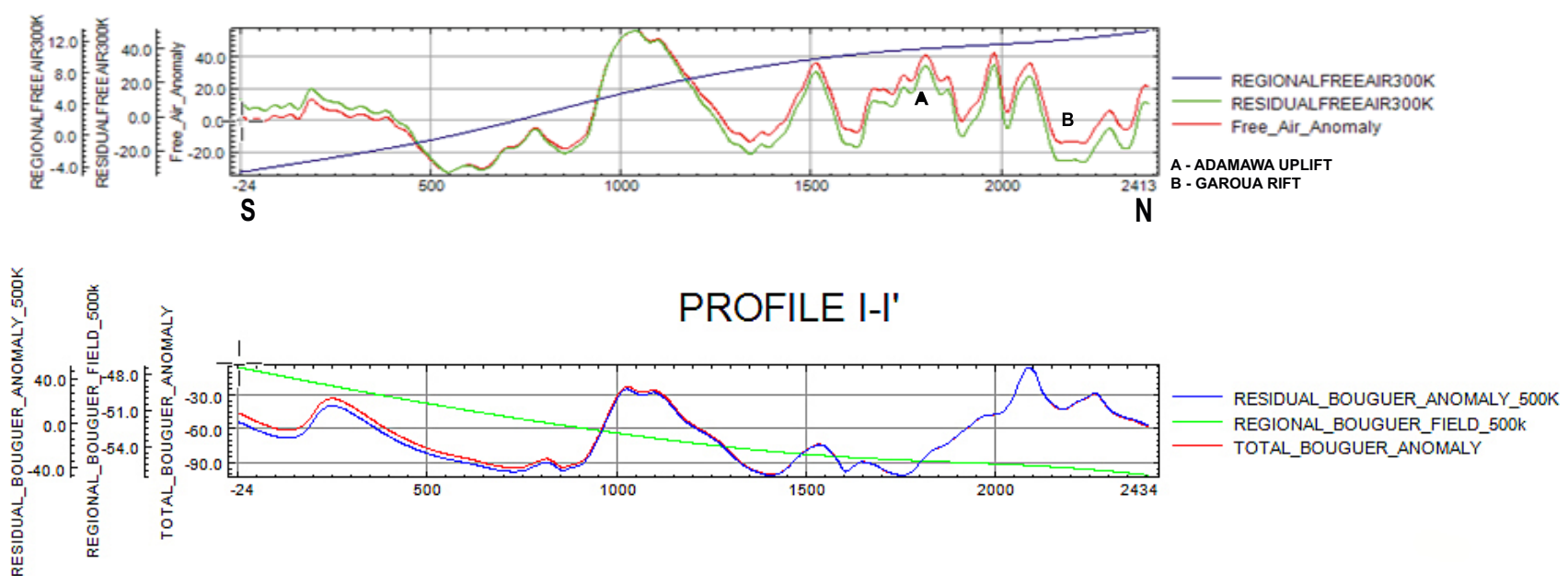

PROFILE I-I'

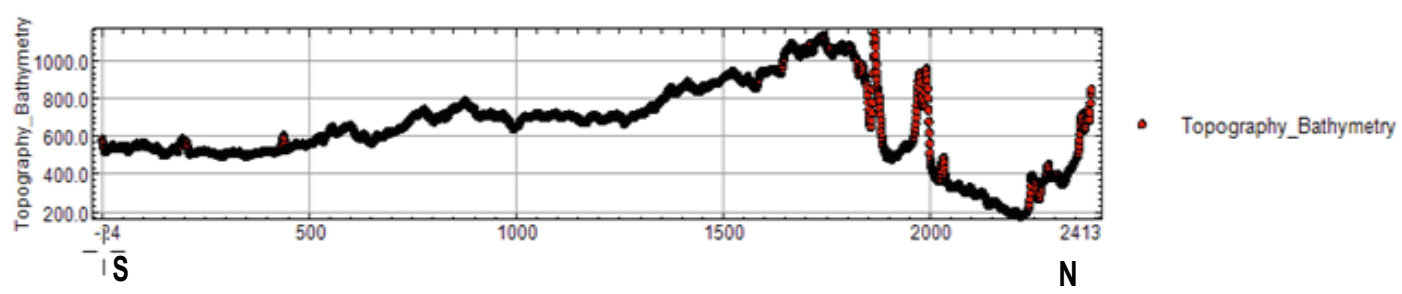

Figure 7(i): Free-air, Bouguer and Topographic/Bathymetric Profiles along 18,200,ooo $\mathrm{mE}$ (i.e. longitude 13.5 $5^{\circ}$ ) 

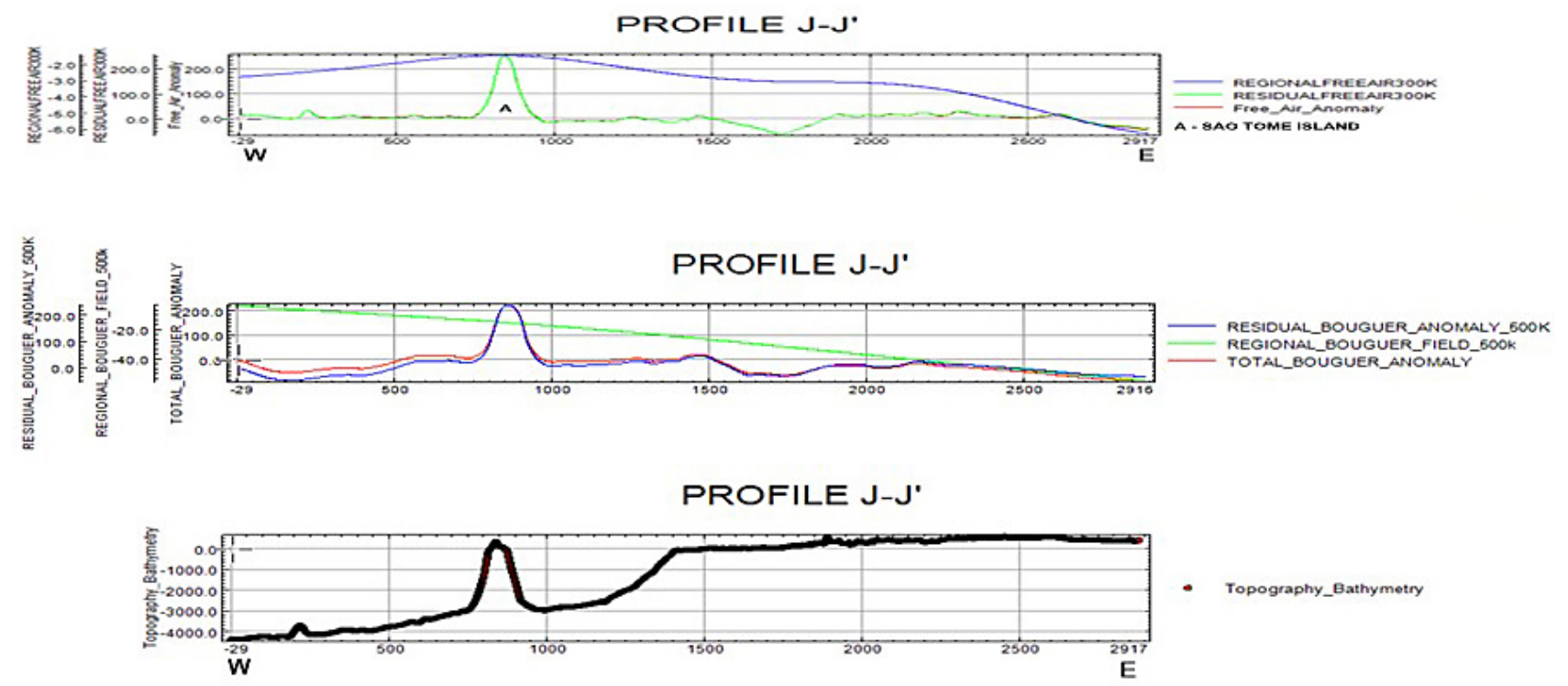

Figure $7(\mathbf{j})$ : Free-air, Bouguer and Topographic/Bathymetric Profiles along 50,ooo mN (i.e. latitude o.45 ${ }^{\circ} \mathrm{N}$ )

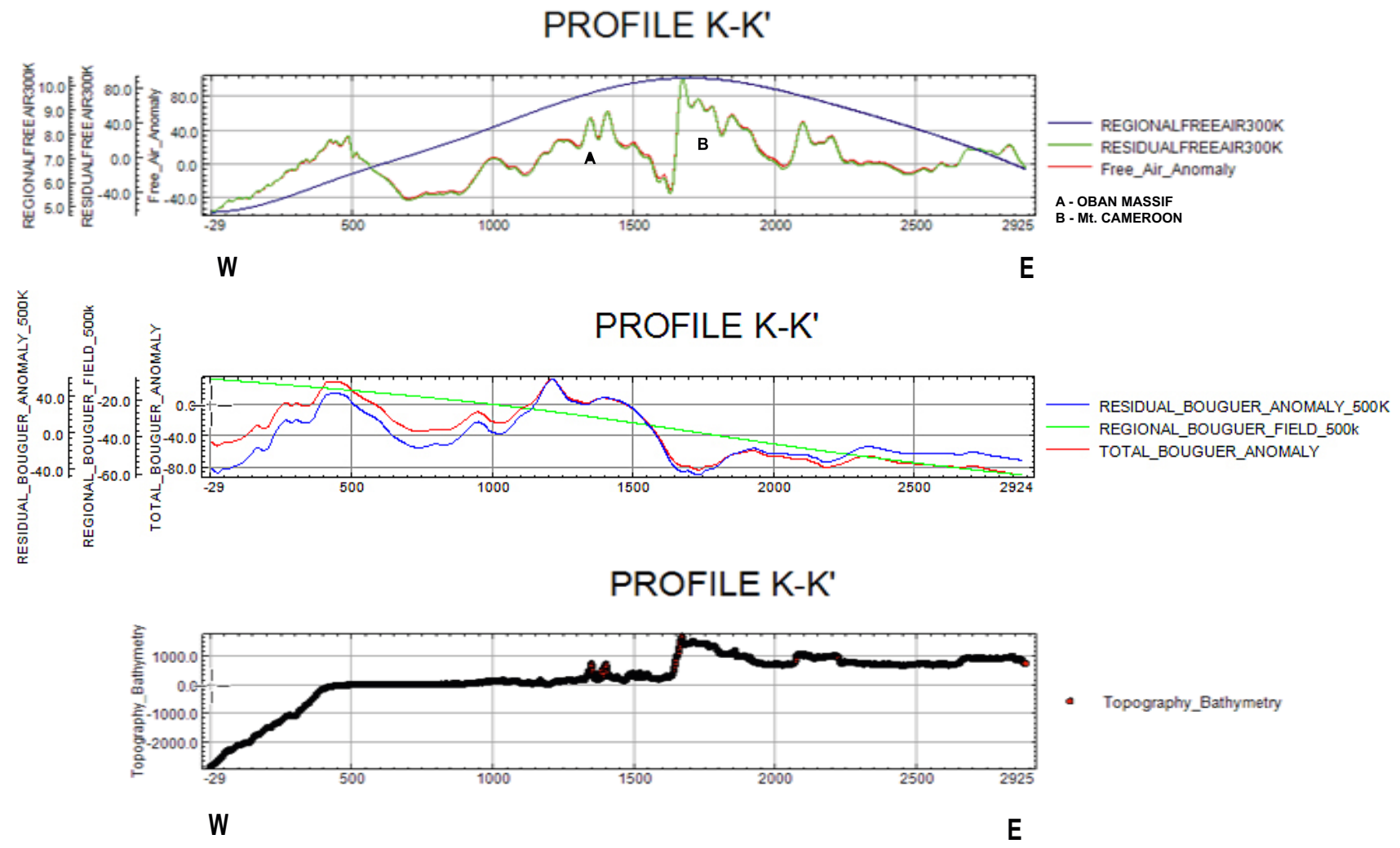

Figure 7 (k): Free-air, Bouguer and Topographic/Bathymetric Profiles along 6oo,ooo $\mathrm{mN}$ (i.e. latitude $5.4^{\circ} \mathrm{N}$ )

\subsubsection{Profile K-K' - Figure $7(\mathbf{k})$}

This is also a West-East running profile. The western end is an oceanic region while the other parts are continental regions. It runs over the Oban Massif and Mount Cameroon. The regional trends were not adequate (not far enough) on this profile as well for both the free-air and Bouguer anomaly profiles.

\subsubsection{Profile L-L' - Figure 7(1)}

This is also a West-East running profile. It runs over the Minna batholith and the Younger Granite Province (Jos Plateau). The regional trend was also not adequate on this profile. The continuous flow of trough minima from West to East on the Bouguer anomaly profile suggests that both the Minna batholith (older granite) and 


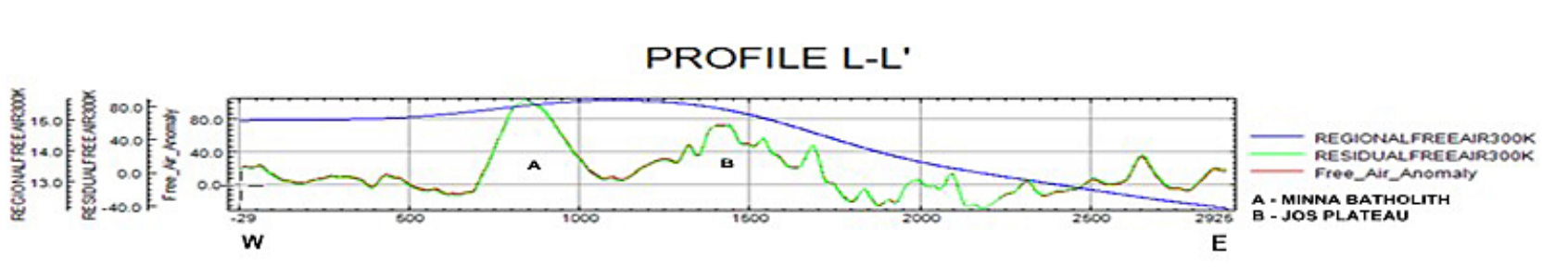

PROFILE L-L'

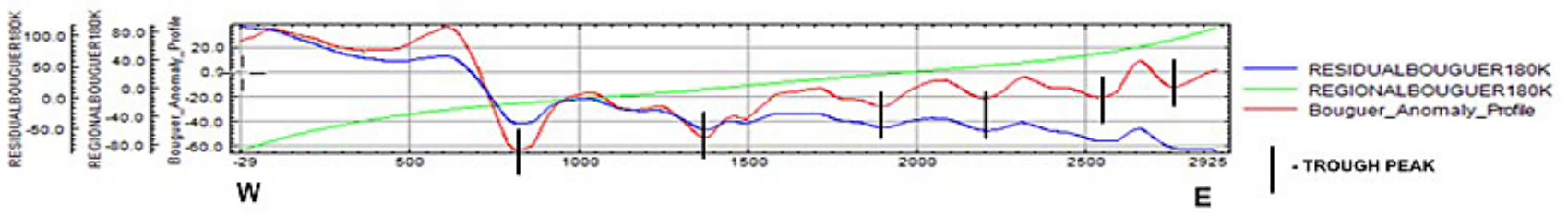

PROFILE L-L'

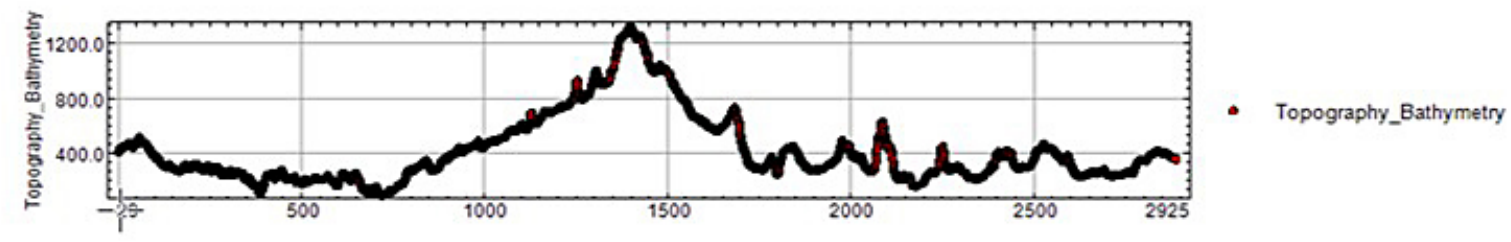

W

E

Figure 7(1): Free-air, Bouguer and Topographic/Bathymetric Profiles along 1,10o,ooo mN (i.e. latitude $10^{\circ} \mathrm{N}$ )

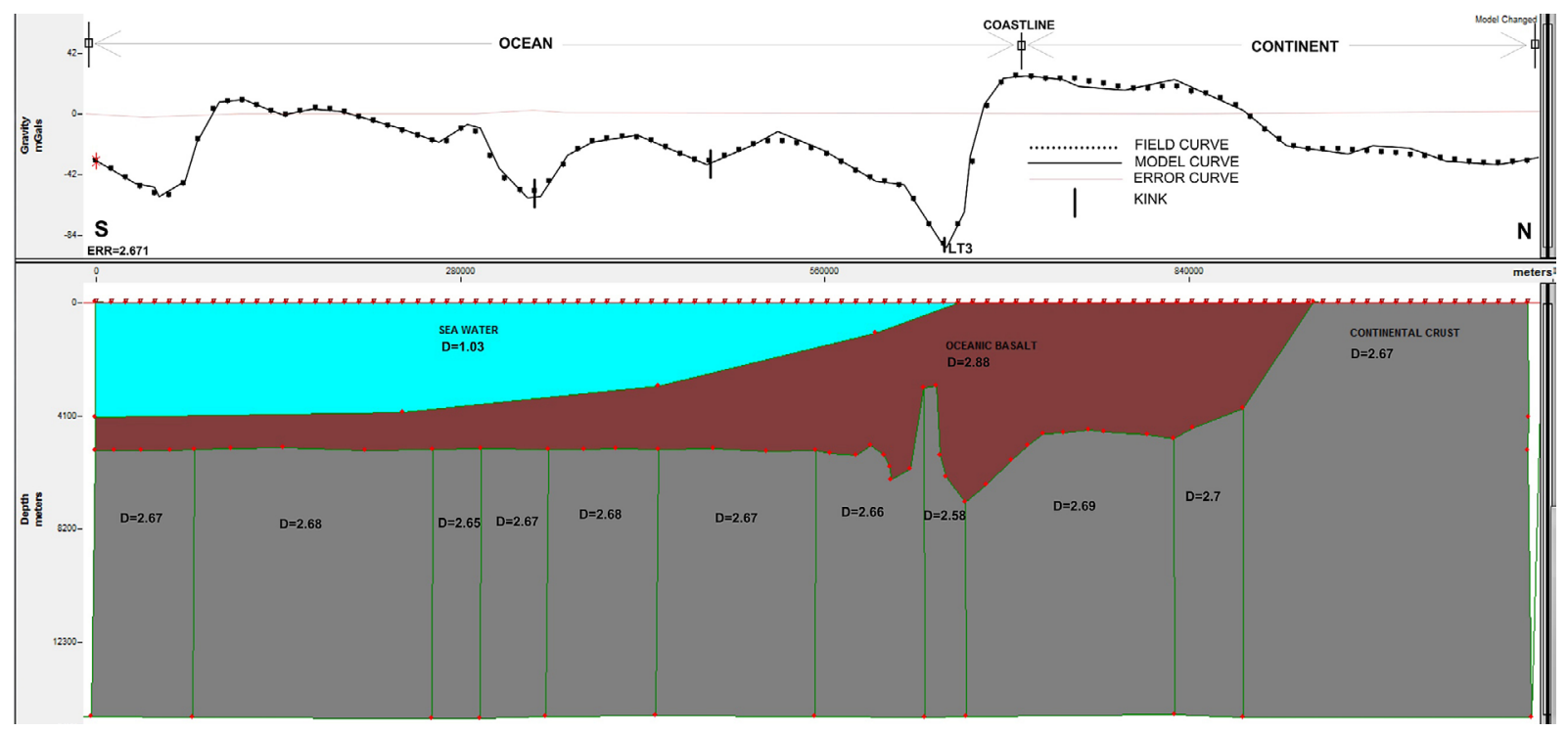

Figure 8(a): 2D Model of the Bouguer Anomaly Profile along Profile A-A'

the Jos Plateau (younger granite) probably exploited the Proterozoic basement weaknesses for their emplacement.

\subsection{The Two- Dimensional Modelling}

Three profiles (Two N-S and One E-W running profiles) were selected for two-dimensional modeling.

\subsubsection{Profile A-A' - Figure 8(a)}

The model generated for Profile A-A' showed the oceanic region and continental margin areas to be underlain by an oceanic basaltic cover with a density of $2.88 \mathrm{gcm}^{-3}$ $\left(2,880 \mathrm{kgm}^{-3}\right)$ whose flow extent seems to be limited to the continental margin, overlying the crustal materials. The thickness of this basaltic cover ranged between 


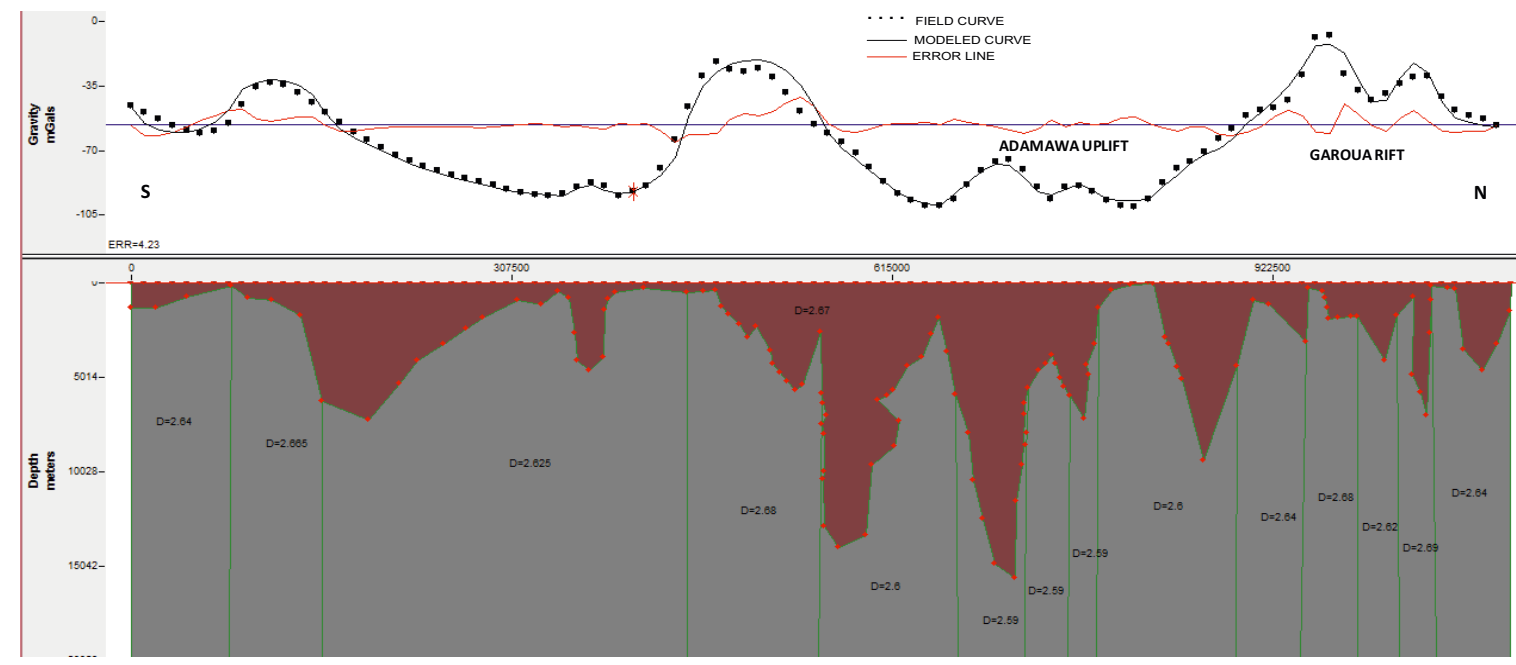

Figure 8(b): 2D Model of the Bouguer Anomaly Profile along Profile I-I'

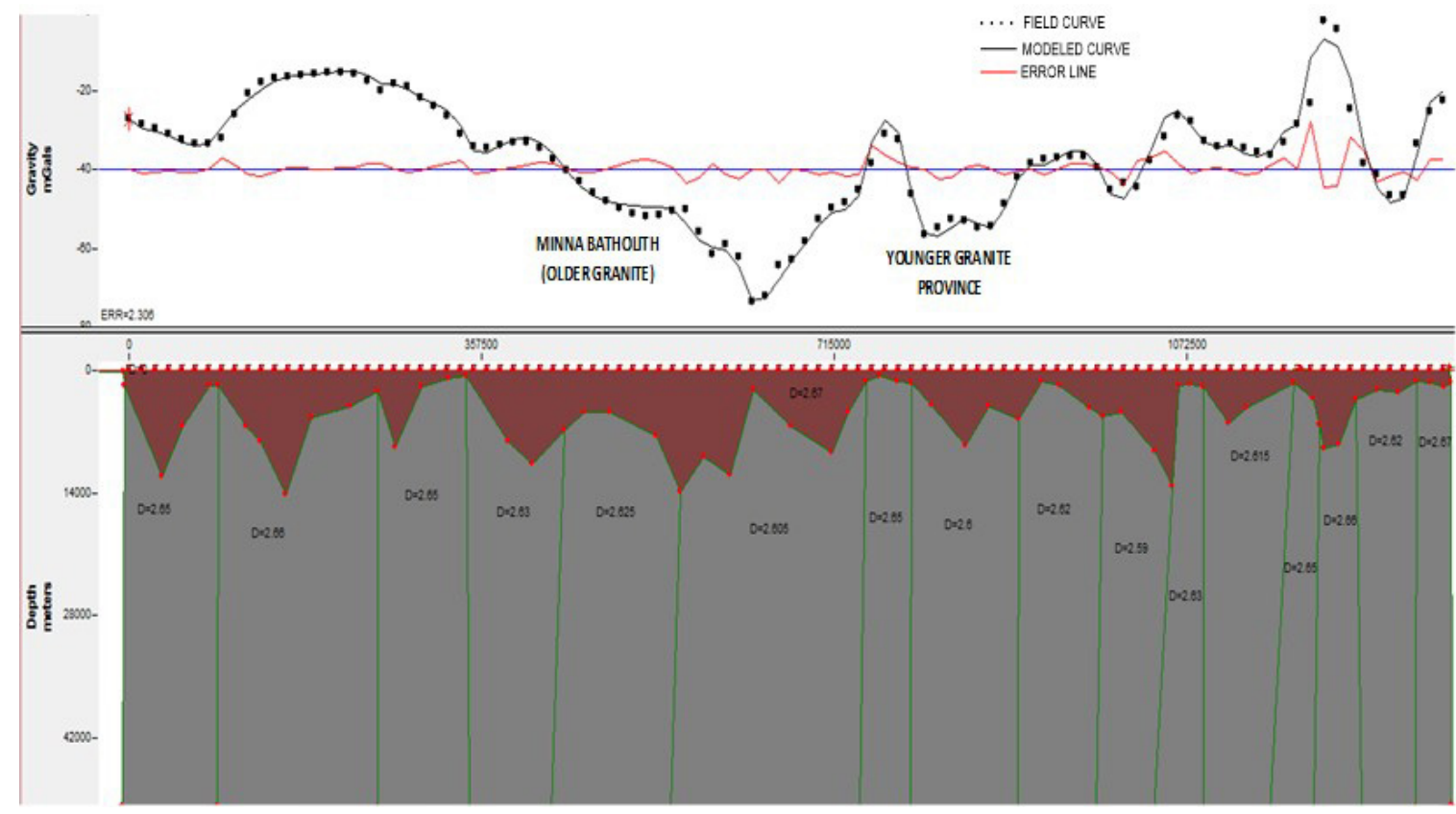

Figure 8(c): 2D Model of the Bouguer Anomaly Profile along Profile L-L'

$1,330 \mathrm{~m}$ and $7,700 \mathrm{~m}$ and is particularly relatively thin under the ocean, occurring between a 4,100 and 5,450 m depth. Observable within the oceanic region also are kinks (LTs) that have earlier been identified as relics of rifting often associated with the formation of a passive basin margin. The model under "LT3" kink revealed a relatively thin basaltic cover and distinct, relatively "lower-density" crustal material underlying this cover with both suggesting volcanic activity from this kink. Thus, the kinks can be considered as fissures for basaltic eruptions. Adjoining the continental margin to the north is the continent.

\subsubsection{Profile I-I' - Figure $8(\mathbf{b})$}

Profile I-I' is a purely continental profile. The trend of the root of the Adamawa Uplift is shown in the model.
The model suggests that the Adamawa Uplift has a root that is as deep as $15 \mathrm{~km}$.

\subsubsection{Profile L-L' - Figure 8(c)}

Profile L-L' is a purely continental profile running over the Older Granite (Minna batholith) and Younger Granite Province (Jos Plateau). It is noticeable on the model that a buoyant underlying crust (ranging between 2,605 and 2,670 $\mathrm{kgm}^{-3}$ ) may have been important in supporting the intrusive Minna batholith and extrusive Jos Plateau.

\subsection{The Derivative Maps}

Figures 9(a) and (b) show the total horizontal derivative maps. On close observation of this derivative map, the following can be deduced: 


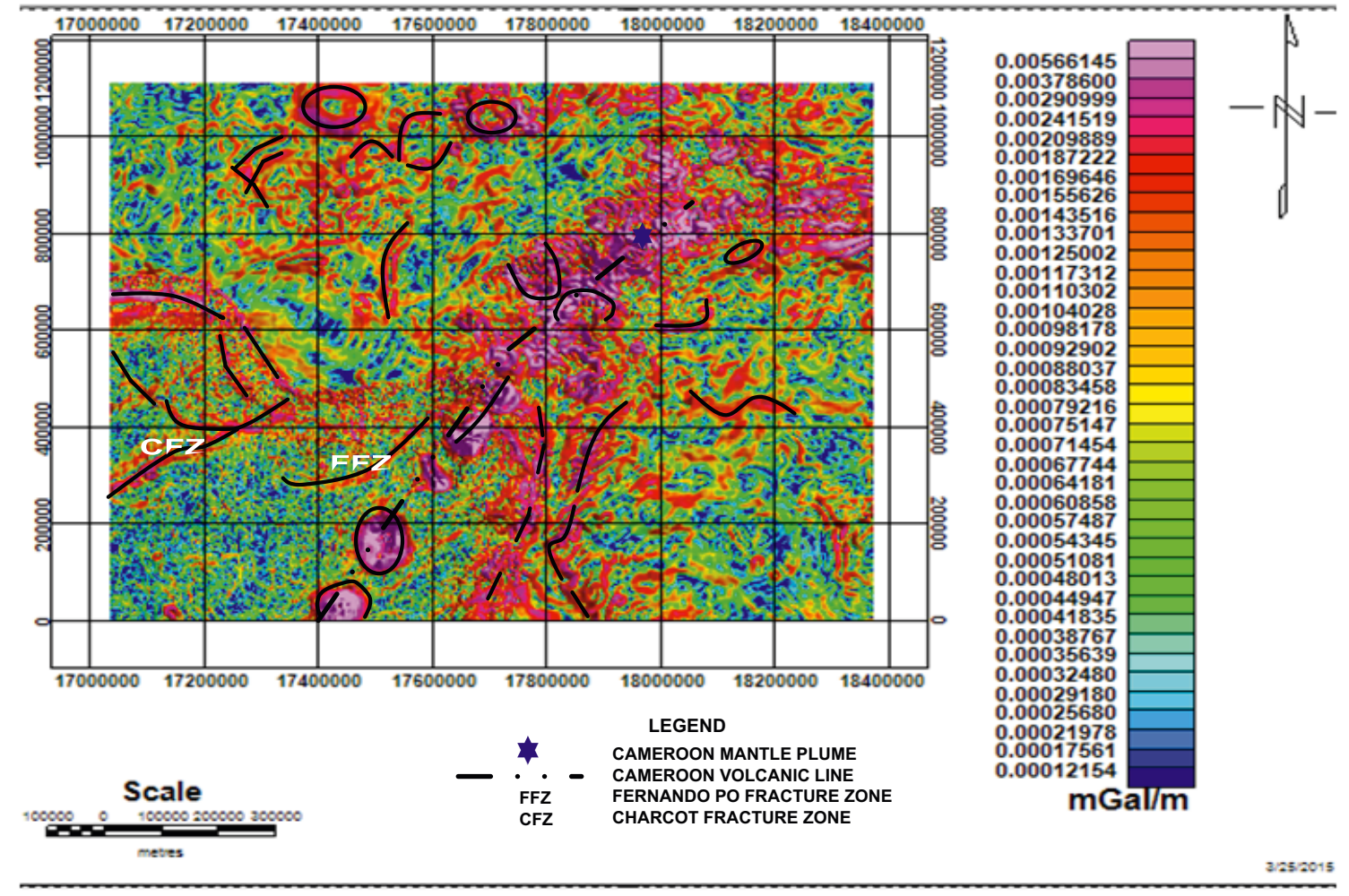

Figure 9(a): Total Horizontal Derivative Map of the Study Area

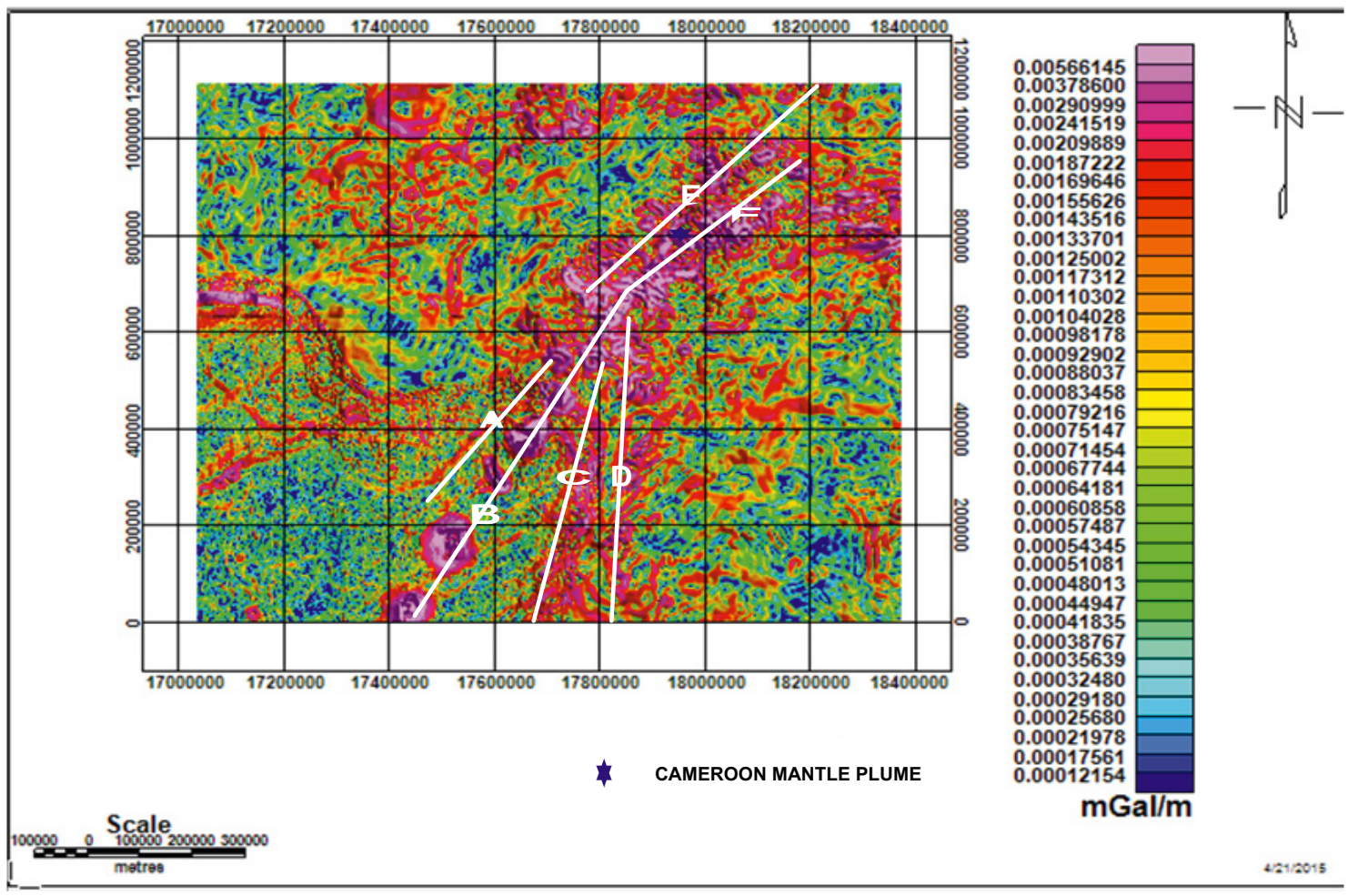

Figure 9(b): Total Horizontal Derivative Map of the Study Area Showing the Benue Trough Migration Pattern

1. The coastline is almost perfectly laced by some curvi-linear trends likely to be magmatism.

2. The African Plate may have probably moved over a line of serial hotspots corresponding to the Cam- eroon Volcanic Line and its continental extension, the Cameroon Mantle Plume (CMP). The imprint of such movements were identified in Figure 9(b) by the NE-SW and ENE-WSW trends labeled A, 
B, C, D, E and F. This then would agree with Fitton (1980)'s proposition who while trying to explain the lack of intense volcanism within the Benue Trough proposed that the Benue Trough is a migrating rift that was once located on the Cameroon Mantle Plume hotspot axis on which the Cameroon Volcanic Line presently lies. Fitton continued that the Benue Trough was once over this hotspot from his studies of the Walvis Ridge (and reconstruction of "Magnetic Anomaly 34") and from the observation that the Benue Trough has a bifurcating arm just like the Cameroon Volcanic Line. It should also be mentioned that the trends labeled $\mathrm{E}$ and $\mathrm{F}$ correspond with the Central African Shear Zone (CASZ).

3. The lineaments labelled CFZ and FFZ on Figure 9(a) correspond to the Charcot Fracture Zone and Fernando Po Fracture Zone respectively.

\section{Conclusion}

The free-air anomaly and Bouguer anomaly profiles revealed that the Equatorial Atlantic Ocean might have opened on a framework of rifts which extended into the inland regions with most of the inland rifts now sedimentary basins. The profiles also revealed that the African West Coast Atlantic margin consists of a trench adjoined just to the north by some high density basalt forming a "low-high" free-air and Bouguer anomaly pair.

The $2 \mathrm{D}$ gravity modelling of the oceanic region revealed a basaltic cover over the crustal material and some characteristic kink anomaly patterns. The model under these oceanic kinks revealed that the kinks are likely to be an expression of "eruption fissures" for basaltic eruption.

As observed from the derivative map, the West African Coastline is heavily laced with magmatism. This magmatism suggests that though the margin is presently seen as a passive margin, it has once been active. The derivative map also seems to agree with the hypothesis of Fitton (1980) that the African lithosphere may have moved over a hot zone in the asthenosphere around the Cameroon Mantle Plume (CMP).

The Bouguer anomaly profile along latitude $10^{\circ} \mathrm{N}$ suggests that it is possible that both the Minna batholith and the Jos Plateau exploited the Proterozoic basement weaknesses for their emplacement.

\section{Acknowledgment}

The authors are grateful to the University of Leeds Industrial Service Limited, Leeds, UK and Scripps Institution of Oceanography, University of California, San Diego, USA for making their data available.

\section{References}

\section{Papers:}

Abdelsalam, M.G., Gao, S.S. and Liégeois, J.P. (2011): Upper mantle structure of the Saharan Metacraton. Journal of African Earth Science, 60(5), 328-336.

Adeleye, D.R. (1974): Sedimentology of the fluvial Bida Sandstones (Cretaceous), Nigeria. Sedimentary Geology, $12,1-24$.

Balogun, O.B., Ojo, S.B. and Olorunfemi, M.O. (2016): Characterization of tectonic lineaments in the central equatorial Atlantic region of Africa from Bouguer anomaly gravity data. Ife Journal of Science, 18(4), 931-947.

Burke, K. and Dewey, J.F. (1974). Two plates in Africa during the Cretaceous. Nature Geoscience, 249, 313-315.

Elsheikh, A.A., Gao, S.S. and Liu, K.H. (2014): Formation of the Cameroun Volcanic Line by lithospheric basal erosion: insight from mantle seismic anisotropy. Journal of African Earth Sciences Elsevier B.V., 100, 96-108.

Fitton, J.G. (1980): The Benue Trough and Cameroon Line-A migrating rift system in West Africa. Earth and Planetary Science Letters, 51, 132-138.

Ngako, V., Affaton, P. and Njonfang, E. (2008): Pan-African tectonics in Northwestern Cameroon: implication for the history of western Gondwana. Gondwana Research, 14, 509-522

Nnange, J.M., Ngako, V., Fairhead, J.D and Ebinger, C.J., (2000): Depths to density discontinuities beneath the Adamawa Plateau region, Central Africa, from spectral analyses of new and existing gravity data. Journal of African Earth Sciences Elsevier B.V., 30, 887-901.

Olade, M.A. (1975): Evolution of Nigeria's Benue Trough (Aulacogen): a tectonical model. Geological Magazine, $112,575-583$.

Petters, S.W. (1978): Stratigraphic evolution of the Benue Trough and its implications for the upper Cretaceous paleogeography of West Africa. J. Geol., 86, 311-322.

Stanley, J.M. (1977): Simplified gravity interpretation by gradients-The geological contact. Geophysics, 42, 1230-1235.

Talwani, M. and Heirtzler, J.R. (1964): Computers in the mineral industries, Part 1, Stanford University Publ., Geological Sciences, 9, 121

Talwani, M., Worzel, J.L. and Landisman, M. (1959): Rapid gravity computations for two-dimensional bodies with application to the Mendocino Submarine Fracture. Journal of Geophysical Research, Vol. 64, 49-59

Won, I.J. and Bevis, M. (1987): Computing the gravitational and magnetic anomalies due to a polygon: Algorithm and FORTRAN subroutines. Geophysics, 52(2), 232-238.

\section{Chapters in books or proceedings with editor(s):}

Doust, H. and Omatsola, E. (1990): Niger Delta. In: Edwards, J.D. and Santogrossi, P.A. (eds.) Divergent/passive margin basins. American Association of Petroleum Geologists, Tulsa, Memoir 48, 239-248 p.

Fairhead, J.D. and Wilson, M. (2005): Plate tectonic processes. In the South Atlantic Ocean: do we need deep mantle 
plumes? The Geological Society of America Special Paper, 388, 537-553 p.

Hoffman, P., Dewey, J.F. and Burke, K. (1974): Aulacogens and their genetic relation to geosynclines with a Proterozoic example from Great Slave Lake, Canada. In: Dott, R. and Shaver, R. (eds.) Modern and ancient geosynclinals sedimentation. Soc. Econ. PaZeont. Miner. Spec PubZ. p. 38-55.

Machens, E. (1973): The geological history of the marginal basins along the north shore of the Gulf of Guinea. In: Nairn, A.E.M. and Stehli, F.G. (eds.) The Ocean basins and margins-The South Atlantic. Plenum Press, New York, pp 351-390

Nwajide, C.S. (1990): Sedimentation and paleogeography of the central Benue Trough, Nigeria. In: Ofoegbu, C. O. (ed.), The Benue Trough Structure and Evolution. ViewegBraunschweig, 19-38 p.

Ojo, S.B. and Ajakaiye, D.E (1976): Preliminary interpretation of gravity measurements in the middle Niger Basin area, Nigeria. In: Kogbe, C.A. (ed.) Geology of Nigeria, Elizabethan Publ. Co. Lagos, 295-307 p.
Phillips J.D. (2000): Locating magnetic contacts: a comparison of horizontal gradients, analytic signal and wave number methods. $70^{\text {th }}$ Annual International meeting, SEG, Expanded Abstracts, pp. 402-405

\section{Book/thesis:}

Telford, W.M., Geldart, L.P. and Sheriff, R.E. (1990): Applied Geophysics, Second Edition. Cambridge University Press, Cambridge, pp 6-84.

Osazuwa, I.B. (1978): Gravity and magnetic survey of upper Benue Trough. Unpublished M.Sc. Thesis, Ahmadu Bello University, Zaria, Nigeria

\section{Internet Sources:}

Hogg, S. GT-Gradient Tensor Gridding, Geologic Structure Example. 2004; URL:http:/www. shapegeophysics.com/ .2004 (accessed 1st October, 2018).

Ramirez, R. (1995): Interpretation of Seafloor Gravity Anomalies. http://geology.uprm.edu/ More-lockSite/morelockonline/1_image/gravanom.ppt (accessed 5th August, 2019).

\section{SAŽETAK}

\section{Analiza i interpretacija gravimetrijskih mjerenja na regionalnoj skali u središnjoj ekvatorskoj atlantskoj regiji Afrike}

U radu su interpretirani regionalni gravimetrijski podatci za središnju ekvatorsku atlantsku regiju Afrike, koja obuhvaća i oceanska i kontinentalna područja. Cilj je bio uvid u njezinu složenu geološku građu, procese i tektonsku evoluciju. Primijenjene su metode izmjere topografije i batimetrije, površinskih (svedenih) i Bouguerovih anomalija na temelju podataka i anomalija mreže, razdvajanja regionalnih i rezidualnih gravimetrijskih podataka, kartiranja lineamenata metodom vodoravne derivacije te 2D modeliranje podzemlja. Unutar kartiranoga područja dubine/visine kretale su se u rasponu od -4200 do $3840 \mathrm{~m}$. Karta anomalija na referentnoj ravnini pokazala je kombinaciju izduženih i kružnih pozitivnih anomalija, ali i negativnih oblika, s vrijednostima između -40 i 70 mGal. Vrijednosti Bouguerovih anomalija kreću se između -121 i 229 mGal. Takva karta također pokazuje izdužene i kružne strukture, pozitivne i negativne. Prevladavajuća orijentacija takvih izduženja jest SI - JZ, I - Z te IJI - ZSZ. Gravimetrijsko modeliranje u oceanskome i prijelaznome kontinentalnom području pokazalo je nazočnost bazalta s debljinom između 1330 i $7700 \mathrm{~m}$. Zajedno s bazaltima dolaze i deformirane stijene kao ostatci pucanja uzrokovanih erupcijama bazalta. Pokazano je kako se atlantski rub zapadnoafričke obale sastoji od jaraka uz kontinentalni rub, koji se pružaju prema sjeveru ispunjeni bazaltom velike gustoće. Zapadnoafrička obala također je snažno obilježena ostatcima magmatizma koji upućuju na veliku magmatsku aktivnost u prošlosti. Zaključeno je kako je ekvatorsko područje Atlantskoga oceana bilo zona riftanja (širenja) koje se širilo prema kopnu i oblikovalo današnje taložne bazene. Profil Bouguerovih anomalija na širini 1o stupnjeva sjeverno upućuje na mogućnost da su batolit Minna i plato Jos istisnuti kroz oslabljeni dio proterozojske podine.

\section{Ključne riječi:}

ravnina svođenja anomalija, Bouguerove anomalije, 2D modeliranje, bazaltni prekrivač, erupcijske pukotine

\section{Authors contribution}

Oluwatimilehin Balogun (Ph.D. Applied Geophysics) plotted and interpreted the maps and profiles, and did the 2-D modelling as well. Olajumoke Akintokewa (M.Sc. Geology) did the derivative analysis, delineated the lineaments and established their geological and tectonic significance in the region. 